\title{
DOCTRINA DEL TRIBUNAL CONSTITUCIONAL DURANTE EL SEGUNDO CUATRIMESTRE DE 2019
}

Doctrine of the Constitutional Court during the second Four-Month Period of 2019

\author{
JUAN CARLOS DUQUE VILLANUEVA \\ Tribunal Constitucional \\ duque@tribunalconstitucional.es \\ CARLOS ORTEGA CARBALLO \\ Tribunal de Cuentas \\ carlos.ortega@tcu.es \\ HERMINIO LOSADA GONZÁLEZ \\ Tribunal Constitucional \\ losada@tribunalconstitucional.es

\section{TOMÁS DE LA QUADRA-SALCEDO JANINI \\ Universidad Autónoma de Madrid \\ tomas.quadra@uam.es}


I. JURISDICCIÓN CONSTITUCIONAL. DERECHO PROCESAL CONSTITUCIONAL. II. FUENTES DEL DERECHO. III. ORGANIZACIÓN TERRITORIAL DEL ESTADO: 1. Sobre los presupuestos de la utilización de la coerción. 2. Sobre la constricción de la autonomía. 3. Sobre los límites y el control jurisdiccional del procedimiento de coerción. 4. Sobre las medidas a adoptar en el procedimiento de coerción. 5. Sobre los órganos intervinientes en la coerción. IV. ORGANIZACIÓN DE LOS PODERES PÚBLICOS. V. DERECHOS FUNDAMENTALES.

\section{JURISDICCIÓN CONSTITUCIONAL. DERECHO PROCESAL CONSTITUCIONAL}

1. La resolución más relevante dictada hasta el momento por el TC en lo que atañe a la organización territorial del Estado es, sin duda, la STC 89/2019 (Pleno), de 2 de julio', que resuelve el recurso de inconstitucionalidad promovido por diputados del Grupo Parlamentario Unidos-Podemos-En Comú Podem-En Marea contra el Acuerdo del Pleno del Senado de 27 de octubre de 2017, por el que se aprueban las medidas requeridas por el Gobierno al amparo del art. 155 CE para garantizar el cumplimiento de las obligaciones constitucionales y para la protección del interés general por parte de la Generalitat de Cataluña.

A los efectos que a este apartado de la crónica interesan, el TC, antes de analizar los motivos de impugnación aducidos por los demandantes, declara, en primer término, que el recurso de inconstitucionalidad es la vía procesal adecuada para la impugnación del acuerdo recurrido por tratarse de un acuerdo con «rango», «fuerza» o "valor» de ley. Con invocación de la doctrina de la STC 83/2016, de 28 de abril $^{2}$ (FF. JJ. 9 y10), y del ATC 7/2012, de 13 de enero ${ }^{3}$ (FJ 3), el TC afirma que aquel acuerdo, al igual que los actos gubernamentales o parlamentarios de declaración o autorización de los estados de emergencia (art. $116 \mathrm{CE}$ ), tiene ese genérico «rango» o «valor de ley», en la medida en que el art. $155 \mathrm{CE}$ permite «la constricción de la autonomía, con

\footnotetext{
Véanse infra pp. 248-260.

2 Reseñada en Revista Española de Derecho Constitucional, núm. 107, 2016, pp. 292 y 295-297.

3 Reseñado en Revista Española de Derecho Constitucional, núm. 95, 2012, pp. 263-265 y 275-277, y núm. 96, 2012, pp. 235-236.
} 
mayor o menor alcance, y, por lo mismo, la inaplicación excepcional de normas estatutarias y legales y su desplazamiento temporal por las reglas mediante las que la cámara, a propuesta del Gobierno, determine las concretas medidas a adoptar por el ejecutivo y discipline el régimen jurídico de esa intervención». En definitiva, las medidas adoptadas al amparo del citado precepto constitucional pueden contener «excepciones o modificaciones pro tempore en la aplicabilidad de determinadas disposiciones legales, que sin ser derogadas o modificadas sí pueden ver alterada su aplicabilidad ordinaria (STC 83/2016, de 28 de abril, FJ 9)» (FJ 2b).

Como segunda consideración previa, el TC entiende que la pérdida de vigencia del acuerdo impugnado no determina la extinción del objeto del proceso, pues, por una parte, ningún ámbito normativo puede devenir inmune al control de la jurisdicción constitucional, y, por otra parte, es indiscutible la relevancia constitucional de la cuestión planteada en el recurso, esto es, los límites formales y materiales de una disposición constitucional de gran importancia para el modelo de organización territorial del Estado como es la del ejercicio del poder de coerción estatal (FJ 2c).

Ambos pronunciamientos se reiteran en la STC 90/2019 (Pleno), de 2 de julio $^{4}$ (FJ 2, b y e), que resuelven el recurso de inconstitucionalidad interpuesto por el Parlamento de Cataluńa contra el mismo Acuerdo del Pleno del Senado. Además en esta última sentencia se excluye como posible objeto del recurso, frente a lo que pretendían la parte recurrente y el Gobierno de la Generalitat, las disposiciones o actos dictados por el Gobierno al amparo del acuerdo impugnado, por tratarse de disposiciones o actos de aplicación que carecen de «fuerza» o "valor» de ley y, por lo tanto, que no pueden ser impugnados a través del recurso de inconstitucionalidad, correspondiendo su control, en tanto que disposiciones y actos infralegales, a la jurisdicción ordinaria (FJ 2a).

En la sentencia también se reconoce a la Diputación Permanente del Parlamento de Cataluña legitimación para promover el recurso de inconstitucionalidad, al corresponderle, expirado el mandato o disuelta la Cámara, «ejercer las facultades parlamentarias en materia de constitucionalidad», entre las que «se encuentra, necesariamente, la de interponer el recurso de inconstitucionalidad cuya promoción corresponde al Pleno cuando está en curso una legislatura». Pronunciamiento que el TC hace extensivo a las diputaciones permanentes de todas las asambleas legislativas autonómicas cuando las cámaras estén disueltas (FJ 2c).

$4 \quad$ Véase nota 1. 
2. El TC desestima en la STC 86/2019 (Pleno), de 20 de junio, la denunciada falta de legitimación de los diputados recurrentes para impugnar una ley autonómica por no haber intentado los miembros del grupo parlamentario de la Asamblea legislativa pertenecientes a la misma formación política que los demandantes enmendar algunos de los preceptos impugnados, así como por haber sido incorporadas al texto de la ley algunas de las enmiendas que presentaron. Frente al óbice de admisibilidad aducido por la representación letrada del Gobierno autonómico, en la sentencia se recuerda que los órganos o sujetos legitimados para promover el recurso de inconstitucionalidad lo están «no en atención a su interés, sino en virtud de la alta cualificación política que se infiere de su respectivo cometido constitucional», de modo que cuando promueven un recurso «están poniendo de manifiesto la existencia de un interés público objetivo en que el Tribunal Constitucional desarrolle su función de garantizar la supremacía de la Constitución mediante el enjuiciamiento de la ley impugnada». A lo que se añade que ni la CE ni la LOTC exigen como condición de legitimación que los recurrentes voten en contra o se abstengan en la aprobación de la ley impugnada. Y, finalmente, se señala que «se ha de desligar la actuación del grupo parlamentario autonómico durante la tramitación de la ley en el Parlamento autonómico de la llevada a cabo por el grupo de diputados del Congreso» que interponen el recurso de inconstitucionalidad, aunque pertenezcan a la misma formación política (FJ 2).

Por su parte, el ATC 71/2019 (Pleno), de 2 de julio, deniega la personación como coadyuvantes de dos asociaciones en el recurso de inconstitucionalidad promovido por el Gobierno contra la Ley del País Vasco 12/2016, de 28 de julio, de reconocimiento y reparación de víctimas de vulneraciones de derechos humanos en el contexto de la violencia de motivación política en la Comunidad Autónoma del País Vasco entre 1978 y 1999, pues, de conformidad con una reiterada doctrina constitucional, la naturaleza abstracta de los recursos de inconstitucionalidad descarta, como regla general, la intervención de cualquier persona distinta a las previstas en los arts. 162.1 a) CE y 32 y 34 LOTC, fueran cuales fueran los intereses que tuvieran quienes se quisieran personar como coadyuvantes en el mantenimiento o en la invalidación de la ley o de los actos y situaciones desarrolladas en su aplicación. A continuación, el TC acepta la solicitud de desistimiento del Gobierno, como consecuencia del compromiso alcanzado con la parte demanda y al haber manifestado su conformidad las demás partes personadas, sin que considere necesario en este caso un pronunciamiento de fondo en razón del interés constitucional del asunto, pues la misma ley ha sido objeto de otro recurso de inconstitucionalidad "con un alcance semejante», que se encuentra pendiente de resolución. 
3. La STC 98/2019 (Pleno), de 17 de julio5, aborda la idoneidad como posible objeto del proceso constitucional de impugnación de disposiciones autonómicas (art. 161.2 CE y título V LOTC) de dos apartados de la Resolución 92/XII del Parlamento de Cataluña, de 11 de octubre, de priorización de la agenda social y la recuperación de la convivencia. La resolución había sido aprobada en el curso de un debate sobre la orientación política general del Gobierno (art. 154 RPC), en la que la Cámara, en los dos apartados objeto de la impugnación, rechazaba y condenaba el posicionamiento del rey y su intervención en el conflicto catalán y su justificación de la violencia ejercida por los cuerpos policiales el día 1 de octubre de 2017 (i), así como reafirmaba su compromiso con los valores republicanos y su apuesta por la abolición de una institución caduca y antidemocrática como la monarquía (ii).

En esta ocasión el debate sobre la idoneidad de los referidos apartados de la resolución parlamentaria como objeto del proceso constitucional se constreñía exclusivamente, en los términos planteados por el letrado del Parlamento de Cataluña, a si carecían o no de efectos jurídicos. El TC, después de traer a colación la doctrina sentada sobre la idoneidad de este tipo de resoluciones como posible objeto de una impugnación de disposiciones autonómicas (SSTC 42/2014, de 25 de marzo $^{6}$, FJ 2, y 259/2015, de 2 de diciembre, FJ 2) y examinar la ubicación sistemática y el contexto en el que se enmarcaban los apartados recurridos, llega a la conclusión de que están dotados de efectos jurídicos.

En lo que al primer apartado se refiere considera que no solo se trata de una declaración política, sino que «también encierra una decisión productora de efectos jurídicos», porque, de una parte, la resolución aprobada «iba dirigida al Gobierno de la Generalitat y a los ciudadanos de Cataluña para darles a conocer cuál era la posición adoptada por el Parlamento sobre la intervención del rey», y, de otra parte, porque les ponía «de manifiesto que la cámara se arrogaba una potestad de censura de aquel acto regio». En lo que atańe al segundo de los apartados impugnados, el TC entiende que se encuentra estrechamente vinculado al apartado anterior $y$, en consecuencia, constituye una "una extensión lógica» del juicio de censura a la intervención del rey, por lo que la conexión que presenta con el primer apartado determina que tiene los mismos efectos jurídicos que este. No obstante, el TC precisa respecto del segundo de los apartados que considerado aisladamente

Véanse infra pp. 260-262.

6 Reseñada en Revista Española de Derecho Constitucional, núm. 106, 2016, pp. 343 y 356.

7 Reseñada en Revista Española de Derecho Constitucional, núm. 101, 2014, pp. 235-237. 
en otra resolución diferente o en un contexto distinto dentro de la misma resolución no tendría "por qué llegar necesariamente a declarar inconstitucional y nulo su texto» (FJ 2).

4. En relación con los conflictos positivos de competencia, el ATC 64/2019 (Pleno), de 21 de mayo, inadmite un conflicto por haber transcurrido en el momento de interposición de la demanda el plazo de un mes previsto en el art. 63.4 LOTC desde la recepción por el órgano autor de la norma del requerimiento de incompetencia formulado por el demandante sin que aquél le hubiera dado respuesta. En este caso no había existido una respuesta tardía al requerimiento de incompetencia que hubiera permitido, según reiterada doctrina constitucional, la reapertura del plazo para la presentación de la demanda.

Por su parte, en el ATC 100/2019 (Pleno), de 18 de junio, el TC inadmite de oficio la impugnación de uno de los preceptos objeto del conflicto por no haber sido incluido en el requerimiento previo de incompetencia (art. 63.3 LOTC), requisito que tiene como finalidad «que el gobierno al que se le imputa la extralimitación competencial pueda conocer la invasión denunciada y, en su caso, corregirla» (FJ 2a). También de oficio el TC excluye como objeto del conflicto uno de los preceptos impugnados por imputársele la carencia de rango legal y, por consiguiente, no revestir este motivo de impugnación carácter competencial, que es la única pretensión o vicio que puede formularse en un conflicto de competencias (FJ 2b).

5. En la STC 64/2019 (Pleno), de 9 de mayo, que resuelve la cuestión de inconstitucionalidad promovida por un órgano judicial por considerar que pudiera ser contrario al art. $18 \mathrm{CE}$ el art. 18.2 de la Ley 15/2015, de 2 de julio, de la jurisdicción voluntaria, que establece la obligación de extender acta detallada de la exploración judicial de un menor, dando traslado a las partes, el TC desestima el óbice de procedibilidad alegado por el Ministerio Fiscal, que califica de insuficiente el juicio de relevancia al no identificar el órgano judicial los datos que en el acta de exploración judicial de la menor extendida en el proceso a quo pudieran afectar a su intimidad, refiriéndose a ellos en el auto de planteamiento de forma hipotética. El TC, atendiendo a los rasgos propios y características del derecho a la intimidad, entiende que en este caso nada ha de reprocharse al juicio de relevancia efectuado por el órgano promotor de la cuestión, pues la ausencia de concreción de los datos que denuncia el Ministerio Fiscal «no altera la sustancia del razonamiento que ha conducido al juez a abrigar dudas sobre la posible vulneración del art. 18.1 CE». En consecuencia, el TC procede a examinar la incidencia que en el expediente de jurisdicción voluntaria presenta el derecho a la intimidad del menor (FJ 3). 
Por su parte, el ATC 39/2019 (Pleno), de 21 de mayo, siguiendo el precedente ATC 84/2012, de 7 de mayo, inadmite una cuestión de inconstitucionalidad por incumplimiento del juicio de aplicabilidad y relevancia, ya que el órgano judicial en el auto de planteamiento omite toda consideración sobre la excepción procesal aducida por la parte demandada en el proceso a quo, pues si dicha excepción — la falta de agotamiento de la vía administrativa previafuera estimada no habría lugar a pronunciarse sobre la pretensión deducida en la demanda y, en consecuencia, el precepto legal cuestionado ni sería aplicable al caso ni sería determinante del fallo (FJ 6).

6. Con ocasión del planteamiento de una cuestión interna de inconstitucionalidad, el TC reitera en la STC 91/2019 (Pleno), de 3 de julio ${ }^{8}$, la doctrina del ATC 3/2019 (Pleno), de 28 de enero (FJ 7), en el sentido de que la Sala al suscitar la cuestión no está constreńida por la demanda de amparo y, por consiguiente, puede ampliar los derechos fundamentales con los que contrastar el precepto legal objeto de la cuestión (FJ 3).

7. En cuanto a los efectos de una declaración de inconstitucionalidad, merece especial atención durante este cuatrimestre la STC 85/2019 (Pleno), de 19 de junio, que estima la cuestión interna de inconstitucionalidad en relación con el art. 294.1 LOPJ, que regula la indemnización a quienes hayan sufrido prisión provisional y hayan sido absueltos o se haya dictado auto de sobreseimiento. En la sentencia se declara la inconstitucionalidad y nulidad de sendos incisos del precepto, en cuanto establecen una diferencia entre supuestos de prisión provisional no seguida de condena contraria al principio de igualdad (art. $14 \mathrm{CE}$ ) y al derecho a la presunción de inocencia (art. 24.2 CE).

El TC, en la fundamentación de la sentencia, reproduce, algo que es realmente infrecuente, el texto del precepto una vez despojado de los incisos declarados inconstitucionales y nulos. Seguidamente precisa que, si bien una interpretación literal del precepto que resulta de aquellas declaraciones permite sostener que «la prisión provisional, cuando el proceso penal concluya con un pronunciamiento de absolución [...] daría lugar a indemnización por los perjuicios irrogados de modo automático y en todos los casos", esta conclusión no se deriva de la sentencia ni de la redacción del art. 294.1 LOPJ depurado de los referidos incisos, debiendo acotar el legislador los presupuestos y el alcance de la indemnización prevista en el citado artículo y, en ausencia de la intervención legislativa, «mediante las interpretaciones congruentes

$8 \quad$ Véanse infra pp. 238 y 263-264. 
con su finalidad y la teoría general de la responsabilidad civil que realicen la administración y, en último término, los órganos judiciales» (FJ 13)9.

8. Los motivos de especial trascendencia constitucional apreciados en los recursos de amparo resueltos durante este cuatrimestre han sido los siguientes: 1) (STC 155/2009, FJ 2a) que el recurso plantea un problema o afecta a la faceta de un derecho fundamental sobre el que no ha doctrina del TC (SSTC 53 y 57/2019, de 6 de mayo, 65, 66, 69 y 70/2019, de 20 de mayo, 77/2019, de 3 de junio [Sala Primera], 54, 58 y 59/2019, de 6 de mayo, 67, 68 y 71/2019, de 20 de mayo, y 81 y 84/2019, de 17 de junio [Sala Segunda] — sentencia dictada sin plantear cuestión prejudicial ante el TJUE cuando no concurrían los requisitos necesarios para apreciar la existencia de «acto aclarado»—; STC 55/2019, de 6 de mayo [Sala Segunda] —resoluciones de letrado de la Administración de Justicia que rechazan la tramitación de escritos procesales por error no imputable al recurrente-; STC 56/2019, de 6 de mayo [Sala Primera] —-marginación laboral de empleado público incursa en abuso de poder o arbitrariedad-; STC 62/2019, de 7 de mayo [Pleno] —impugnación de medida cautelar de prisión provisional comunicada y sin fianza-; STC 75/2019, de 22 de mayo [Pleno] — sanción disciplinaria penitenciaria por hacer uso de una llamada telefónica para difundirla en un mitin electoral—; SSTC 83/2019, de 17 de junio, y 94 y 95/2019, de 15 de julio [Sala Primera] —impedimento de acceso a los elementos de las actuaciones que resultan esenciales para impugnar la legalidad de la privación de libertad en un proceso en el que se ha declarado el secreto del sumario-; STC 97/2019, de 16 de julio [Pleno] —consideración de la denominada «lista Falciani» como prueba lícita de cargo-); 2) (STC 155/2009, FJ 2b) que el recurso de amparo puede dar ocasión al TC para aclarar o cambiar su doctrina como consecuencia de un proceso de reflexión interna (STC 96/2019, de 15 de julio ${ }^{10}$ [Sala Segunda] —resoluciones parlamentarias que acuerdan la tramitación de una proposición de ley por el procedimiento de lectura única-); 3) (STC 155/2009, FJ 2c) que la posible vulneración del derecho fundamental que se denuncia pudiera provenir de la ley o de otra disposición de carácter general (STC 80/2019, de 17 de junio [Sala Segunda] —resoluciones judiciales que acuerdan el sobreseimiento de causa penal al apreciar la falta de

9 A la sentencia formularon sendos votos particulares discrepantes la vicepresidenta Roca Trías y los magistrados Narváez Rodríguez y Enríquez Sancho, que firmaron un voto conjunto.

10 También se apreció como motivo de especial trascendencia constitucional que el asunto suscitado trasciende del caso concreto y pudiera tener unas consecuencias políticas de alcance general (STC 155/2009, FJ 2g). 
competencia jurisdiccional de los tribunales españoles por hallarse fuera del ámbito de la soberanía española las personas extranjeras procesadas por la comisión de delitos de guerra fuera del territorio nacional—; STC 92/2019, de 15 de julio [Sala Segunda] —resoluciones administrativas y jurisdiccionales sobre cuantía de pensión de jubilación de los trabajadores a tiempo parcial en aplicación de un precepto declarado inconstitucional y nulo por incurrir en discriminación indirecta—; STC 93/2019, de 15 de julio [Sala Segunda] — resoluciones de letrado de la Administración de Justicia que impiden el control judicial de lo actuado en expediente de jura de cuentas-); 4) (STC 155/2009, FJ 2e) que la doctrina del TC sobre el derecho fundamental que se alega podría estar siendo incumplida de modo general o reiterado por la jurisdicción ordinaria o pudieran existir resoluciones judiciales contradictorias sobre el derecho fundamental (SSTC 73/2019, de 20 de mayo, y 78/2019, de 3 de junio [Sala Segunda] - condena en segunda instancia sin la previa audiencia de los acusados-); y 5) (STC 155/2009, FJ 2f) que el órgano judicial pudiera haber incurrido en una negativa manifiesta del deber de acatamiento a la doctrina del TC (STC 61/2019, de 6 de mayo [Sala Primera] —no incorporación a las actuaciones de escrito de alegaciones y documentación aneja por defectuoso funcionamiento de Lexnet y de la oficina judicial—; STC 72/2019, de 20 de mayo [Sala Segunda] inadmisión de petición de habeas corpus por razones de fondo-; STC 82/2019, de 17 de junio [Sala Segunda] —emplazamiento edictal en procedimiento administrativo sancionador sin haber agotado las posibilidades del emplazamiento personal—, y STC 88/2019, de 1 de julio [Sala Segunda] — condena en segunda instancia sin haber dado al acusado la posibilidad de dirigirse al tribunal-).

En relación con el motivo de la especial trascendencia constitucional consistente en que el órgano judicial pudiera haber incurrido en una negativa manifiesta del deber de acatamiento a la doctrina del TC (STC 155/2009, FJ 2f), se declara en la STC 82/2019, de 17 de junio (Sala Segunda), que, aunque en su enunciado está exclusivamente referido a actuaciones o resoluciones judiciales, tal circunstancia no impide que pueda apreciarse también en relación con la actuación de la Administración en un procedimiento sancionador a la que le sería imputable en su origen la lesión del derecho fundamental denunciada. En efecto, el TC entiende que el control de constitucionalidad que tiene que llevar a cabo en el recurso de amparo, dado el carácter subsidiario de este, no debe limitarse a la concreta actuación lesiva del derecho fundamental, sino que ha de extenderse al funcionamiento en conjunto del sistema de protección de los derechos fundamentales, por lo que el deber de acatamiento a su doctrina constitucional se impone tanto a las Administraciones públicas como a los tribunales que revisan su actuación (FJ 2). 
De otra parte, en el ATC 40/2019 (Sección Segunda), de 22 de mayo, se desestima el recurso de súplica promovido por el Ministerio Fiscal contra la inadmisión de un recurso de amparo por no justificar suficientemente la especial trascendencia constitucional (art. 49.1 LOTC), promovido contra las resoluciones judiciales que declararon el sobreseimiento provisional de una causa por haber transcurrido el plazo máximo de seis meses sin que se declarara su complejidad y sin que ninguna de las partes hubiera solicitado la prórroga de la instrucción (art. 324 LECrim.). La Sección considera que, aunque el demandante había invocado como uno de los motivos de especial trascendencia constitucional que la vulneración denunciada provenía de la ley o de una disposición de carácter general (STC 155/2009, FJ 2c), sin embargo, en la demanda no se discutía la constitucionalidad del citado art. 324 LECrim y las quejas se dirigían «únicamente a los órganos judiciales quienes habrían vulnerado el artículo $24 \mathrm{CE}$ por acordar o confirmar el sobreseimiento provisional». De modo que la Sección entiende que la invocación de aquel motivo de especial trascendencia constitucional era meramente "nominal, huérfana de contenido», igual que la del resto de los motivos de especial trascendencia constitucional aducidos que "carecen de argumentación suficiente» sin que en la demanda se disocien «las razones que evidenciarían, de un lado, la especial trascendencia constitucional del recurso y, de otro, las vulneraciones denunciadas» ${ }^{11}$.

9. La STC 75/2019 (Pleno), de 22 de mayo, inadmite a trámite por extemporáneo el recurso de amparo promovido por don Jordi Sánchez i Picanyol contra la sanción disciplinaria impuesta por la comisión disciplinaria del centro penitenciario en el que se encontraba interno, confirmada por el Juzgado de Vigilancia Penitencia, por hacer uso de una llamada telefónica con el fin de que fuera difundida en un mitin electoral. El TC entiende que el objeto del recurso es el acto administrativo, puesto que en la demanda se plantean vulneraciones constitucionales (principio de legalidad penal —art. 25

11 Al auto formuló voto particular discrepante la magistrada Balaguer Castejón, a quien la respuesta que se da al recurso de súplica del Ministerio Fiscal le parece «excesivamente rigorista, dada la función de este Tribunal de velar por la garantía de los derechos fundamentales del artículo $24 \mathrm{CE}$. En su opinión la demanda contiene una «extensa exposición de razonamientos [...] en $1[\mathrm{o}]$ s que se desgranan cuatro motivos» de especial trascendencia constitucional «que ponen en conexión las vulneraciones constitucionales que se alegan en la demanda [...] con los criterios del artículo 50.1.b)». Concluye el voto sosteniendo su autora que «el rigorismo empleado para inadmitir a trámite este recurso de amparo no se cohonesta con la postura mantenida por este Tribunal en otros asuntos». 
CE— y derecho al acceso de cargos públicos — art. 23.2 CE—) causadas en su origen por el acuerdo sancionador, limitándose a señalar respecto de las decisiones del Juzgado de Vigilancia Penitenciaria que vienen a confirmar la resolución administrativa impugnada, sin que contra estas decisiones se formule alguna queja autónoma que permita considerar el recurso de amparo como un recurso de amparo mixto. Al tratarse de un recurso de amparo del art. 43 LOTC, no del art. 44 LOTC, ni mixto, el plazo para su interposición es el de veinte días desde la notificación de la resolución recaída en la vía judicial previa, plazo que había transcurrido cuando se interpuso la demanda de amparo.

En la sentencia se recuerda «el carácter instrumental que tiene la vía judicial previa al amparo constitucional en relación con el acto que produjo la vulneración del derecho, en tanto que las decisiones producidas en esta vía judicial no han de ser objeto de impugnación por la sola razón de no haber estimado la pretensión deducida por el recurrente», pues de lo contrario habría que entender «que no hay más actos u omisiones atacables en vía de amparo constitucional que los actos u omisiones de los órganos judiciales» (FJ 3 $)^{12}$.

10. En relación con el requisito del agotamiento de la vía judicial previa del art. 44.1.a) LOTC, el TC considera en la STC 55/2019 (Sala Segunda), de 6 de mayo $^{13}$, que no cabe estimar incumplido dicho requisito por no haber

12 A la sentencia formularon voto particular discrepante los magistrados Valdés Dal-Ré, Xiol Ríos y Balaguer Callejón, para quienes «el recurso de amparo debe ser calificado como un recurso mixto, al tener la vulneración alegada del derecho a la legalidad sancionadora (artículo 25.1 CE) su origen, formal y materialmente en las resoluciones judiciales impugnadas, por lo que las reglas procesales de admisibilidad son las previstas en el artículo 44 LOTC, entre ellas que el plazo de interposición es de treinta días». Consideran necesario «insistir en la distorsión que supone en el marco de la ley orgánica de este Tribunal la diferencia de plazos entre aquellos recursos de amparo en que las vulneraciones de derechos fundamentales sean originadas por actuaciones administrativas (art. 43 LOTC) o por actuaciones judiciales (art. 44 LOTC)», pues dicha diferencia «no responde a ningún motivo objetivo, sino a la mera desatención del procedimiento legislativo de aprobación de la citada Ley Orgánica 6/2007) [...] [d] e este modo, no es infrecuente encontrar supuestos dudosos, como el presente, en el que el demandante resulta sorprendido con una decisión de inadmisión por extemporaneidad, incluso en sentencia». «El legislador — sostienen los autores del voto - tiene la responsabilidad de solucionar esta inexplicable e injustificable diferencia de régimen, unificando el plazo de ambos preceptos mediante una reforma legislativa».

13 Véanse infra pp. 267-269. 
intentado forzar el demandante una resolución judicial contra las resoluciones del letrado de la Administración de Justicia, bien interponiendo un recurso que no está previsto legalmente (art. 188.1 de la Ley 36/2011, de 10 de octubre, reguladora de la jurisdicción social), bien promoviendo un incidente de nulidad de actuaciones, que solo cabe en los casos en los que no se haya podido denunciar la lesión del derecho fundamental y siempre contra resoluciones dictadas por órganos judiciales. Asimismo, el TC entiende que no procede en este caso acordar la retroacción de actuaciones para que el demandante pudiera interponer recurso de revisión contra las resoluciones del letrado de la Administración de Justicia, como se había habilitado en la STC 72/2018, de 21 de junio, hasta que el legislador no instrumentase otro recurso, por estimar desproporcionada una decisión de inadmisión que impidiese entrar en el fondo de una demanda correctamente formalizada para colmar una subsidiariedad que no podía exigirse a la parte a la fecha de interponer la demanda, «sino una subsidiariedad sobrevenida, con efectos retroactivos en su perjuicio y no prevista legalmente». En consecuencia — concluye el TC—, la carga de interponer recurso de revisión contra las resoluciones de los letrados de la Administración de Justicia para estimar agotada la vía judicial previa, como se dispuso en la STC 72/2018, solo es exigible para las resoluciones de los letrados de la Administración de Justicia notificadas a partir de la fecha de publicación de aquella sentencia en el Boletín Oficial del Estado (FJ 2) ${ }^{14}$.

\section{FUENTES DEL DERECHO}

La jurisprudencia constitucional durante el período considerado en la presente crónica no ofrece novedad en materia de fuentes del derecho.

1. Como ya anticipábamos en la crónica del cuatrimestre precedente, la doctrina de la STC 37/2019 (Pleno), de 26 de marzo (asunto del «bono social eléctrico»), conforme a la cual el TC parece pretender reforzar su posición de garante del principio de primacía del derecho de la Unión Europea, ha sido reiterada por sentencias de ambas Salas, que estiman los recursos de amparo interpuestos por la Administración General del Estado porque el Tribunal Supremo resolvió el asunto declarando inaplicable el precepto legal en el que se fundaba el reglamento recurrido, al entenderlo incompatible con la Directiva 2009/72/CE, sin plantear la cuestión prejudicial ante el Tribunal de

14 Juan Carlos Duque Villanueva. 
Justicia de la Unión Europea (TJUE). En el período que abarca esta crónica se han dictado las SSTC 53/2019, 54/2019 y 57/2019 (Sala Segunda), todas de 6 de mayo; las SSTC 58/2019 y 59/2019 (Sala Primera), ambas de 6 de mayo también; las SSTC 65/2019, 66/2019, 69/2019 y 70/2019 (Sala Segunda), todas de 20 de mayo; las SSTC 67/2019, 68/2019 y 71/2019 (Sala Primera), todas de 20 de mayo también; la STC 77/2019 (Sala Segunda), de 3 de junio, y las SSTC 81/2019 y 84/2019 (Sala Primera), ambas de 17 de junio.

Procede, en consecuencia, remitirse a lo ya señalado en la reseña de la STC 37/2019 ${ }^{15}$, y basta con advertir ahora de que la Sala de lo Contencioso-Administrativo del Tribunal Supremo, en cumplimiento de lo decidido por el TC, ha acordado por auto de 9 de julio de 2019 plantear cuestión prejudicial ante el TJUE.

2. La STC 76/2019 (Pleno), de 22 de mayo, que estima el recurso de inconstitucionalidad planteado por el Defensor del Pueblo contra el art. 58 bis de la Ley Orgánica de Régimen Electoral General, incorporado por la Ley Orgánica 3/2018, de 5 de diciembre, de protección de datos personales y garantía de derechos digitales (precepto que permitía a los partidos políticos la recopilación de datos personales relativos a las opiniones políticas de los ciudadanos), reitera la conocida doctrina constitucional según la cual los instrumentos del derecho de la Unión Europea (en este caso, el Reglamento 2016/679, del Parlamento Europeo y del Consejo, de 27 de abril de 2016, Reglamento general de protección de datos) que inciden sobre derechos fundamentales constituyen, a tenor del art. 10.2 CE, y al igual que los textos internacionales sobre derechos humanos, «valiosos criterios hermenéuticos del sentido y alcance mínimo de los derechos y libertades que la Constitución reconoce» (aquí, del derecho a la protección de los datos personales, art. 18.4 CE); si bien «no constituyen canon para el enjuiciamiento de la adecuación a la Constitución de normas dotadas de rango legal» (FJ 3, con cita a su vez de la STC 140/2018, de 20 de diciembre, FJ 6) ${ }^{16}$. El TC esquiva el problema afirmando que el derecho fundamental a la protección de los datos personales «se halla parcialmente determinado por el Derecho de la Unión Europea» (la cursiva es nuestra), pero lo cierto es que el Reglamento general de protección de datos, directamente aplicable, tiene vocación de exhaustividad, de suerte que el derecho fundamental a la protección de datos personales, protegido por el art. 18.4 CE, pasa a ser directa y principalmente regulado por una norma europea. La Ley Orgánica 3/2018 se limita a adaptar el ordenamiento español

15 Reseñada en Revista Española de Derecho Constitucional, núm. 116, 2019, pp. 234-235.

16 Reseñada en la Revista Española de Derecho Constitucional, núm. 115, 2019, p. 271. 
al Reglamento (UE) 2016/679 y a clarificar y complementar sus disposiciones, dentro del margen que la propia norma europea establece.

En sentido similar, la STC 91/2019 (Pleno), de 3 de julio ${ }^{17}$, que estima la cuestión interna de inconstitucionalidad planteada por la Sala Segunda y declara la nulidad parcial de un precepto de la Ley general de la seguridad social sobre cálculo de la pensión de jubilación en caso de trabajo a tiempo parcial, por vulnerar el derecho a la igualdad de trato e incurrir en discriminación indirecta (art. 14 CE), reitera el valor hermenéutico, en virtud del art. 10.2 CE, de los instrumentos del derecho de la Unión Europea que inciden sobre derechos que la Constitución reconoce, en particular conforme a la interpretación sentada por la jurisprudencia del TJUE (FJ 7). En el concreto supuesto sometido al enjuiciamiento del TC, la doctrina sentada por el TJUE en su sentencia de 8 de mayo de 2019, asunto C-161/18, Villar Láiz, resultará a la postre determinante para apreciar que el precepto legal cuestionado incurre en discriminación indirecta por razón de sexo, por cuanto que la diferencia de trato que establece el precepto cuestionado «no solo conduce a un resultado perjudicial en el disfrute de la protección de la seguridad social para los trabajadores contratados a tiempo parcial, sino que afecta predominantemente a las mujeres trabajadoras, como revelan los datos estadísticos» (FJ 9) ${ }^{18}$.

3. Por su parte, la STC 80/2019 (Sala Segunda), de 17 de junio, que deniega el amparo solicitado por los familiares de un periodista español fallecido en Bagdad como consecuencia del impacto de un proyectil disparado por un carro de combate estadounidense, reitera la doctrina constitucional

Véanse, supra, p. 231, e, infra, pp. 263-264.

18 Paradójicamente, el recurso de amparo que dio lugar al planteamiento de la cuestión interna de constitucionalidad (art. 55.2 LOTC) resuelta por la STC 91/2019 no fue interpuesto por una mujer, sino por un varón, por lo que en principio puede resultar chocante que se hable de discriminación indirecta por razón de sexo. La STC 91/2019, FJ 3, sale al paso de esta objeción remitiéndose a los argumentos contenidos en el auto de la Sala Segunda de planteamiento de la cuestión interna (ATC 3/2019, de 28 de enero, FJ 7): si bien el recurrente del proceso a quo no es una mujer, la norma cuestionada resulta de aplicación a todos los trabajadores a tiempo parcial y desde luego le fue aplicada al recurrente, lo que permite a la Sala cuestionar el precepto también desde la perspectiva de la discriminación indirecta por razón de sexo. Ahora bien, si esto puede ser válido para el enjuiciamiento abstracto del precepto legal aplicado al recurrente, dudosamente podría serlo para resolver el recurso de amparo en el que se planteó la cuestión interna de inconstitucionalidad; justamente por ello ese recurso de amparo es estimado por STC 92/2019 (Sala Segunda), de 15 de julio, pero solo por vulneración del derecho del recurrente a la igualdad ante la ley. 
(por todas, STC 140/2018, de 20 de diciembre) según la cual el control por los órganos judiciales de la adecuación del derecho interno a las exigencias de los convenios internacionales constituye una cuestión de selección de la norma aplicable, perteneciente al ámbito de la legalidad ordinaria, por lo que al TC solo le compete en la vía del recurso de amparo revisar la selección del derecho formulada por los jueces ordinarios bajo el parámetro del art. 24.1 CE, todo ello sin perjuicio del valor hermenéutico de los textos internacionales de garantía de los derechos humanos, en virtud de la cláusula del art. 10.2 CE. En suma, «el análisis de convencionalidad que tiene cabida en nuestro ordenamiento constitucional no es un juicio de validez de la norma interna o de constitucionalidad mediata de la misma, sino un mero juicio de aplicabilidad de disposiciones normativas; de selección de derecho aplicable, que queda, en principio, extramuros de las competencias del Tribunal Constitucional» (FJ 2).

4. La STC 63/2019 (Pleno), de 9 de mayo, desestima un recurso de inconstitucionalidad interpuesto por más de cincuenta diputados del grupo parlamentario Unidas Podemos contra diversos preceptos de la Ley 9/2017, de 8 de noviembre, de contratos del sector público, por estimar que la regulación controvertida, al permitir que los servicios públicos de gestión indirecta puedan financiarse mediante la aportación de los usuarios, que pasa a ser denominada como "tarifa», con la naturaleza de prestación patrimonial de carácter público no tributario. Para los recurrentes, la regulación impugnada vulnera los principios de igualdad y reserva de ley en el ámbito tributario (arts. 14 y 31.3 CE), así como el principio de universalidad presupuestaria (art. 134.2 $\mathrm{CE}$ ); consideran que existe una exigencia constitucional de que se aplique un sistema de financiación mediante tributos (tasas) a todos los servicios públicos, con independencia de la forma de prestación y gestión, directa o indirecta, cuando concurra alguna de las notas determinantes de la coactividad, esto es, que se trate de servicios de prestación obligatoria, de solicitud o recepción indispensable, y monopolísticos.

La STC 63/2019 rechaza la tesis de los diputados recurrentes. Recuerda la doctrina constitucional conforme a la cual el alcance de la reserva de ley es distinto tanto entre las diferentes prestaciones patrimoniales de naturaleza tributaria como entre las que son tributarias y las que no lo son. En el específico supuesto de las prestaciones patrimoniales de carácter público no tributarias «lo que determina y justifica la reserva de ley es la coactividad», y lo esencial es que su establecimiento se lleve a cabo bien por la propia ley, bien con arreglo a la misma, lo que exige que sea una norma legal la que establezca los criterios a partir de los cuales deben cuantificarse, de acuerdo con los fines y principios de la legislación sectorial en la que en cada caso se inserte (FJ 5). 
Sentado lo anterior, el TC afirma que así como la CE y la doctrina constitucional no imponen un determinado modelo de gestión de los servicios públicos, tampoco imponen un concreto modelo de financiación de los servicios públicos en función del modo de gestión y prestación de estos: su determinación forma parte del ámbito de configuración del legislador. En consecuencia, "la atribución de una determinada naturaleza jurídica a las denominadas tarifas es una decisión del legislador, el cual, dentro de los límites constitucionales, está habilitado para decidir el régimen a aplicar a las contraprestaciones que han de abonar los usuarios de los servicios públicos». Por otra parte, la regulación controvertida «colma la reserva de ley para este tipo de contraprestaciones, pues establece los criterios generales con arreglo a los cuales, en el marco de la legislación de contratos del Estado, deberán revisarse las correspondientes tarifas», configuradas por el legislador como prestaciones patrimoniales de carácter público no tributario. No existe, en suma, infracción de la reserva de ley del art. 31.3 CE en la regulación impugnada (FJ 6).

Tampoco aprecia el TC vulneración del principio de igualdad (art. 14 $\mathrm{CE}$ ), pues nada se acredita por los recurrentes sobre la supuesta diferencia de trato discriminatoria entre los usuarios de los servicios públicos. Rechaza, por último, que pueda producirse la pretendida infracción del principio de universalidad presupuestaria (art. 134.2 CE), toda vez que una nota definitoria de las prestaciones patrimoniales de carácter público no tributarias es que no suponen necesariamente un ingreso público en sentido estricto, lo que por lógica implica que no figuren en el estado de ingresos de los presupuestos públicos. Ello no determina una falta de control sobre el coste, como sostienen los recurrentes, pues la ley de contratos contiene reglas específicas acerca de la contabilización de las tarifas en función del tipo de contrato de que se trate, a efectos del control y supervisión por parte de la Administración contratante, concluye el TC (FJ 7) ${ }^{19}$.

\section{ORGANIZACIÓN TERRITORIAL DEL ESTADO}

1. En el segundo cuatrimestre de 2019 la conflictividad por motivos competenciales ante el TC se ha mantenido relativamente baja. Así, el Estado ha interpuesto en ese período cinco recursos de inconstitucionalidad frente a distintas leyes autonómicas por motivos competenciales y las comunidades autónomas han interpuesto dos recursos de inconstitucionalidad y un conflicto positivo de competencias frente a normas del Estado.

19 Herminio Losada González. 
2. En relación con las concretas sentencias dictadas, cabe destacar, en primer lugar, la STC 79/2019 (Pleno), de 5 de junio, que resuelve el recurso de inconstitucionalidad interpuesto por el presidente del Gobierno contra el artículo primero, apartado 5, de la Ley de las Cortes de Castilla-La Mancha 2/2018, de 15 de marzo, por la que se modifica la Ley 3/2015, de 5 de marzo, de caza.

El precepto autonómico impugnado dispone:

[...] la responsabilidad de la indemnización por los daños agrícolas, forestales o ganaderos producidos por especies cinegéticas provenientes de zonas de seguridad motivadas por la existencia de autopistas, autovías, líneas férreas o infraestructuras hidráulicas, será del titular de la infraestructura. Dicho titular será, además, el responsable de controlar en la zona de seguridad las especies cinegéticas que provoquen este tipo de daños.

El abogado del Estado alega, en primer lugar, la vulneración del régimen de distribución de competencias entre el Estado y las comunidades autónomas, ya que, al hacer derivar la norma autonómica la responsabilidad por los daños sobre los cultivos de la mera titularidad de las infraestructuras de cuya zona de seguridad provengan las especies, se excluye la exigencia de una conexión causal con el servicio prestado. Exigencia que se recoge en el sistema de responsabilidad patrimonial de las Administraciones públicas que se establece en el art. 32 de la Ley 40/2015, de 1 de octubre, de Régimen Jurídico del Sector Público (LRJSP), aprobado al amparo de la competencia que corresponde al Estado en virtud del art. 149.1.18 CE y en relación con el art. 106.2 CE.

En segundo lugar, el abogado del Estado alega que la norma autonómica que establece dicho régimen de responsabilidad, y determina que el titular de la infraestructura será el responsable de controlar en la zona de seguridad las especies cinegéticas que provoquen este tipo de daños, al proyectarse no solo sobre infraestructuras que son competencia de la comunidad autónoma, sino sobre infraestructuras que son competencia del Estado, vulneraría las competencias que al Estado corresponden conforme a lo dispuesto en el art. 149.1.21 y $24 \mathrm{CE}$.

El TC comienza recordando a la comunidad autónoma que cualquier consideración sobre la falta de impugnación de disposiciones vigentes en otras comunidades autónomas y de contenido idéntico o similar al del objeto del proceso resulta completamente irrelevante.

En cuanto al fondo, se destaca en la STC 79/2019 que la regulación controvertida establece dos tipos de obligaciones: una de control y otra de indemnización. Dichas obligaciones se imponen a los titulares de determinadas 
infraestructuras (autopistas, autovías, líneas férreas o infraestructuras hidráulicas) y consisten, por una parte, en controlar, en las zonas de seguridad de dichas infraestructuras, a las especies cinegéticas que provoquen daños agrícolas, forestales o ganaderos, por otra, en imponer a los titulares de dichas infraestructuras la responsabilidad de indemnización por dichos daños, producidos por las referidas especies cinegéticas.

En cuanto a la articulación de la norma autonómica, aprobada conforme a la competencia exclusiva de la comunidad autónoma en materia de caza, con el sistema de responsabilidad de las Administraciones públicas establecido en el art. 32 LRJSP, recuerda la STC 79/2019 que al Estado le corresponde establecer el régimen de responsabilidad de las Administraciones públicas, si bien:

[...] el art. 149.1.18 C.E. no puede excluir que, además de esa normativa común que representa el sistema de responsabilidad para todo el territorio, las comunidades autónomas puedan establecer otros supuestos indemnizatorios en concepto de responsabilidad administrativa, siempre que, naturalmente, respeten aquellas normas estatales con las que en todo caso habrán de cohonestarse y sirvan al desarrollo de una política sectorial determinada.

La regulación autonómica contravendría los requisitos dispuestos en el art. 32 LRJSP y en el art. 149.1.18 CE, si se entiende que la misma establece como único título de imputación la titularidad de la infraestructura, sin tener en cuenta si los daños pueden conectarse causalmente con el servicio prestado o no.

Sin embargo, para el TC cabe una interpretación conforme del precepto impugnado, pues la regulación establece no solo la obligación de indemnización, sino también la obligación de los titulares de las infraestructuras de controlar las especies cinegéticas que provocan daños en los cultivos y que habitan en las zonas de seguridad como consecuencia de la existencia de dichas infraestructuras. Así, para el TC podría entenderse que se establecería una relación de causalidad entre el funcionamiento de los servicios públicos, la proliferación de determinadas especies cinegéticas en las zonas de seguridad de las infraestructuras, la obligación de controlar aquellas especies y el daño que producen las mismas en los cultivos adyacentes.

De ello se infiere que la obligación de indemnización prevista en el precepto autonómico impugnado solo surgiría cuando los daños son atribuibles al funcionamiento del servicio público, concurriendo así los elementos previstos en el art. 32 LRJSP. Esta interpretación es llevada al fallo.

No obstante lo anterior, el TC declarará la inconstitucionalidad del precepto autonómico en cuanto supone la imposición de obligaciones que 
afectan al normal funcionamiento de las infraestructuras de titularidad estatal, pues considera que el legislador autonómico no puede imponer obligaciones específicas (la de controlar las especies cinegéticas que provoquen determinados daños y, en su caso, la de indemnizar por los mismos) a aquellas sin tener en cuenta los intereses estatales en presencia, ni hacer intento alguno de cohonestar la competencia autonómica con las sectoriales estatales.

La STC 79/2019 no declara la nulidad del precepto por tal motivo, pues el precepto continuaría siendo aplicable a infraestructuras de titularidad de otras Administraciones públicas y, por lo tanto, considera que el mismo no ha de declararse nulo sino solo inconstitucional en cuanto a las infraestructuras de titularidad estatal.

3. La STC 87/2019 (Pleno), de 20 de junio, resuelve el recurso de inconstitucionalidad interpuesto por el presidente del Gobierno contra distintos artículos de la Ley del Parlamento de Cataluña 16/2017, de 1 de agosto, del cambio climático.

El recurso es estrictamente competencial, pues se denuncia la vulneración de las competencias estatales en materia de bases y coordinación de la planificación general de la actividad económica (art. 149.1.13 CE), puertos de interés general (art. 149.1.20 CE), legislación, ordenación y concesión de recursos y aprovechamientos hidráulicos cuando las aguas discurran por más de una comunidad autónoma (art. 149.1.22 CE), legislación básica sobre protección del medio ambiente (art. 149.1.23 CE) y bases del régimen minero y energético (art. 149.1.25 CE). Asimismo, se impugna el impuesto sobre las emisiones de dióxido de carbono de los vehículos previsto en la ley autonómica por contrario al art. 6.2 y 3 de la LOFCA.

La STC 87/2019, tras señalar que en la Constitución y en el Estatuto de Autonomía de Cataluña no existe ningún título competencial específico relativo a la lucha contra el cambio climático, recuerda que en pronunciamientos anteriores el propio TC ha encuadrado competencialmente aquellos planes y programas de ayudas públicas dirigidas a generar actividad económica baja en carbono y a contribuir al cumplimiento de los compromisos internacionales asumidos por España sobre reducción de emisiones de gases de efecto invernadero en el art. 149.1.23 CE.

Sin embargo, subraya el TC que la ley del cambio climático de Cataluña no persigue solo la protección del medio ambiente; representa también, al mismo tiempo, el diseño de un modelo energético y económico alternativo para todas las actividades productivas y la programación o planificación de la actividad administrativa necesaria para alcanzar ese objetivo. Para el TC, no es posible prescindir de los intereses económicos y energéticos implicados y de 
las reglas de distribución de competencias en esas materias, en concreto, en cuanto a su planificación.

Ello significa que, teniendo en cuenta el contenido y finalidad de la ley impugnada, no es posible relegar los títulos de energía y economía al papel un tanto secundario o adjetivo, no sustancial, apreciado en la doctrina previa del propio TC que había encuadrado, como se ha señalado, las cuestiones relativas al cambio climático únicamente en el art. 149.1.23 CE (por ejemplo, en las SSTC 15/2018, de 22 de febrero ${ }^{20}$, y 62/2018 y 64/2018, de 7 de junio) ${ }^{21}$.

Es al enjuiciar cada precepto concreto a la luz de la normativa estatal de contraste cuando habrá de identificarse, según el TC, el título competencial más específico y prevalente o, en su caso, la confluencia de varios de ellos (protección del medio ambiente, ordenación de la actividad económica y energía), a los efectos de resolver sobre su constitucionalidad.

No obstante lo anterior, tal identificación no parece muy necesaria en la práctica, pues la propia STC 87/2019 señala que, siendo objeto de enjuiciamiento una norma autonómica, «lo relevante no será tanto el engarce competencial de la ley autonómica en general o de cada precepto impugnado en particular como el carácter formal y materialmente básico de la legislación estatal de contraste», y la existencia de una "contradicción efectiva e insalvable por vía interpretativa» entre esa normativa y el precepto en cada caso recurrido. Ciertamente ello será así en el caso de contradicciones de la norma autonómica con una estatal dictada con fundamento en una competencia básica en materia de energía o economía, pero no lo sería si el encuadre fuese el de medio ambiente, pues en tal supuesto la comunidad autónoma sí dispondría de la capacidad de establecer normas adicionales de protección.

No obstante lo anterior, el debate sobre cuál debe ser el encuadre competencial de las medidas sobre el cambio climático se ve enriquecido por la aparición de nuevos argumentos en la STC 87/2019.

Así, en efecto, el TC señala que una "transición energética» tan importante, diseñada con el detalle de los preceptos autonómicos, excede con mucho la perspectiva estrictamente medioambiental y aun energética, y no puede perder de vista las variadas implicaciones que trae consigo la alternativa al modelo vigente en materia económica, de reestructuración o reconversión industrial, empleo, cohesión territorial, competitividad de las empresas, formación de trabajadores, educación, etcétera, intereses todos ellos cuya tutela encuentra acomodo en otros títulos competenciales de la Constitución y los

20 Reseñada en Revista Española de Derecho Constitucional, núm. 113, 2018, pp. 255-258.

21 Reseñadas en Revista Española de Derecho Constitucional, núm. 114, 2018, p. 206. 
estatutos de autonomía que por fuerza deben entenderse igualmente concernidos e implicados en la decisión.

Para el TC el nivel de coordinación exigido y de recursos que deben ser movilizados por los poderes públicos para poder alcanzar o aproximarse a los objetivos señalados y los efectos de la transformación pretendida exceden con mucho el ámbito territorial y el poder de decisión de una comunidad autónoma.

He aquí un nuevo criterio de determinación de los límites competenciales a las comunidades autónomas: como el nivel de coordinación exigido y de recursos que deben ser movilizados para poder alcanzar realmente los objetivos de lucha contra el cambio climático excede de la capacidad autonómica, estas no tienen competencia para abordarlo. En realidad, aunque no lo explicita, la STC 87/2019 estaría considerando que la competencia del Estado sobre el cambio climático se fundamentaría entonces en su imposible asunción por los estatutos de autonomía, en razón de su naturaleza, y de ahí derivaría su consiguiente atribución al Estado, pues cabe deducir entonces que esta falta de asunción estatutaria, que es inevitable en razón de la naturaleza de las cosas, desembocaría en que en virtud del art. 149.3 CE la competencia sea una competencia estatal. En realidad, la competencia del Estado no se basaría en los títulos enumerados en el 149.1 sino en la cláusula residual del 149.3 CE. Evidentemente, la STC 87/2019 no llega tan lejos y simplemente afirma que la competencia sobre cambio climático no puede ser autonómica ex propria rerum natura. Así se desprende de la STC 87/2019 cuando afirma que no pueden las comunidades autónomas decidir libre, aislada e individualmente si, y en su caso, cómo, afrontan esta "transición energética», y la fecha en que debe conseguirse esta, a modo de dies ad quem. Para el TC «solo el Estado se encuentra en la posición y tiene las herramientas para decidir y planificar esa transformación».

En relación con los concretos preceptos impugnados, el TC aplica en buena medida doctrina previa para resolver muchas de las controversias suscitadas, y así, por ejemplo, declara inconstitucional el precepto que prohíbe, de manera absoluta e incondicionada, el otorgamiento de permisos de exploración para trabajos que requieran la técnica del fracking, o el precepto que establece la necesidad de diseñar un sistema de tarifas que penalice el sobreconsumo, pues se opone a la doctrina que establece que la regulación de un régimen económico único para todo el territorio nacional tiene naturaleza básica.

Igualmente, considera la STC 87/2019, que perseguir «la transición energética hacia un modelo cien por cien renovable, desnuclearizado, descarbonizado [y] neutro en emisiones de gases de efecto invernadero", como disponen los apartados primero y segundo del art. 19 de la ley autonómica, no pasaría 
de ser una directriz programática constitucionalmente legítima que por sí sola no vulneraría competencias estatales. Sin embargo, según la STC 87/2019, este art. 19 recogido en la norma autonómica va más allá de esta directriz, pues impone objetivos concretos, detallados, a término, mensurables y, por tanto, vinculantes, como los de reducir el consumo de energía un $2 \%$ anual «para llegar como mínimo al $27 \%$ en el ańo 2030» y reducir el consumo de combustibles fósiles al $50 \%$ en 2030 y a 0 en 2050.

Señala el TC como las normas estatales vigentes prevén un sistema energético enteramente opuesto en el que se admite, por ejemplo, el uso de combustibles fósiles y que no aparece sujeto a plazo. Para la STC 87/2019, la ley autonómica contradice las determinaciones básicas del modelo energético establecidas por el Estado.

Ello lleva a la STC 87/2019 a declarar la nulidad de aquellas letras del art. 19.1 que, según el TC, imponen la implantación a término de un modelo energético concreto incompatible con el regulado y permitido por las bases estatales, y deja, sin embargo, subsistente la directriz o pauta programática relativa a "la transición energética hacia un modelo cien por cien renovable, desnuclearizado, descarbonizado [y] neutro en emisiones de gases de efecto invernadero", pues se puede referir a una serie de medidas que no tienen que ser necesariamente imperativas, ni traducirse en la prohibición de uso de combustibles fósiles o energía nuclear.

Lo más llamativo es que la norma autonómica en los incisos declarados nulos no establecía realmente una prohibición de uso de los combustibles fósiles, por lo que cabía perfectamente que el TC hubiese realizado una interpretación conforme en la línea de considerar que el impulso de un modelo energético en que el consumo de combustibles fósiles tienda a ser nulo en unos determinados plazos deberá ser respetuoso con la distribución competencial, pues cabría perfectamente aceptar que la comunidad autónoma promoviese una política de fomento del consumo nulo de tales combustibles mediante un sistema de incentivos para el que sí sería competente.

Así, en alguno de los casos de los preceptos declarados nulos por la STC 87/2019, puesto que la ley autonómica no realiza, en puridad, materialmente, una regulación de la cuestión, sino que se refiere a la necesidad de hacer algo para alcanzar los objetivos de lucha contra el cambio climático, el TC podría haber interpretado que tales medidas se deberían desarrollar en el ámbito de las competencias respectivas.

No ha optado, sin embargo, el TC por acudir a la técnica de la interpretación conforme o a considerar alguna de las impugnaciones como preventivas y ha acabado declarando la nulidad de una buena parte de la norma autonómica. 
Más allá de la aplicación de la doctrina previa para resolver la mayoría de las cuestiones controvertidas, cabe, sin embargo, destacar por su novedad alguno de los pronunciamientos de la STC 87/2019.

Así, cabe destacar un relevante obiter dictum a efectos futuros y es aquel en el que se suscita la cuestión de si las normas autonómicas que prohíben bien la fabricación bien la comercialización de determinados productos por razones medioambientales pueden incurrir en inconstitucionalidad por vulnerar la normativa estatal dictada en ejercicio de competencias reconocidas en otros títulos del art. 149.1 CE, como es el título sobre ordenación de la economía del art. 149.1.13 CE, o, por el contrario, se encontrarían amparadas en la capacidad autonómica, ex art 149.1.23 CE y el respectivo estatuto de autonomía, de dictar normas adicionales de protección en materia medioambiental. Así, de acuerdo con la STC 87/019, una norma que prohibiese la fabricación de vehículos motorizados nuevos de combustión interna fósil a partir de una concreta fecha podría dar lugar a una vulneración de las competencias estatales en materia de tráfico y circulación de vehículos a motor (art. 149.1.21 CE), o, prosigue el TC, en materia de industria, que forma parte del art. 149.1.13 CE y comprende la «ordenación de sectores industriales» y, en particular, las «actividades públicas relacionadas con la fabricación y homologación de productos industriales —en este caso, de vehículos—».

Finalmente, y en una línea sostenida en los últimos tiempos en relación con el rechazo de las impugnaciones estatales de impuestos autonómicos, la STC 87/2019 considera que el impuesto catalán sobre las emisiones de dióxido de carbono de los vehículos de tracción mecánica no grava el mismo «hecho imponible», en el sentido del art. 6.2 LOFCA, que el impuesto especial sobre determinados medios de transporte, pues de los «elementos centrales» del impuesto estatal no puede afirmarse que este sea un impuesto medioambiental, sino un impuesto sobre el consumo de ciertos bienes para uso particular. Es un impuesto fundamentalmente fiscal, aunque pueda encontrarse en él algún rastro extrafiscal orientado a la protección del medio ambiente; el impuesto autonómico, por el contrario, aparece vinculado al principio "quien contamina paga». Así, en efecto, el impuesto autonómico grava las «emisiones de dióxido de carbono» por los vehículos afectados, mientras que el impuesto estatal grava la "primera matriculación» de los medios de transporte que sujeta a tributación. De acuerdo con este presupuesto de la tributación, el primero es un impuesto periódico, y el segundo, instantáneo. La cuota tributaria del impuesto estatal depende del precio o valor de mercado del vehículo en el momento de la adquisición, aunque el tipo de gravamen se fije en función de las emisiones contaminantes, mientras que el impuesto autonómico prescinde completamente del precio o valor del vehículo, y de su 
uso particular o empresarial, y toma solamente en consideración para calcular la cuota tributaria el dato de las emisiones contaminantes.

4. Las SSTC 89/2019 y 90/2019 (Pleno), de 2 de julio ${ }^{22}$, abordan por primera vez de forma directa la interpretación del alcance del procedimiento de coerción estatal previsto en el art. $155 \mathrm{CE}$.

Las referidas resoluciones del TC resuelven sendos recursos de inconstitucionalidad planteados por más de cincuenta diputados del Grupo Parlamentario Unidos-Podemos-En Comú Podem-En Marea y por el Parlamento de Cataluńa contra el Acuerdo del Pleno del Senado, de 27 de octubre de 2017, mediante el que se aprueban medidas requeridas por el Gobierno al amparo del artículo 155 de la Constitución.

A los efectos que a este apartado de la crónica interesan, lo más relevante de las SSTC 89 y 90/2019 es la doctrina general que se realiza del alcance de la coerción estatal en nuestro ordenamiento jurídico. De tal doctrina general cabe examinar las siguientes cuestiones por considerarse las más relevantes: los presupuestos fácticos de la utilización de la coerción, la coerción como constricción de la autonomía, los límites y el control jurisdiccional del procedimiento de coerción, las medidas a adoptar en el procedimiento de coerción o los órganos intervinientes en la coerción.

\section{SOBRE LOS PRESUPUESTOS DE LA UTILIZACIÓN DE LA COERCIÓN}

El TC caracteriza al procedimiento de coerción estatal previsto en el art. $155 \mathrm{CE}$ como un procedimiento extraordinario previsto para imponer el "cumplimiento forzoso» a una comunidad autónoma incumplidora de sus obligaciones constitucionales o legales, o para proteger el interés general de España frente al que aquella hubiere atentado gravemente.

El TC recalca así los dos presupuestos que justificarían poner en marcha el art. $155 \mathrm{CE}$, pues considera que, en su tenor literal, el precepto diferencia, por un lado, la actuación autonómica que suponga un «atentado grave al interés general de España», y, por otro, el «incumplimiento de las obligaciones que la Constitución u otras leyes» impongan a la comunidad autónoma. Diferencia que supone considerar que con la mención al atentado al interés general de España - supuesto incluido por el constituyente sin que estuviese en el precepto alemán, el art. 37 de la Ley Fundamental alemana, que sirvió de modelo al precepto español-, el art. $155 \mathrm{CE}$ ha destacado un supuesto en el que se

22 Véanse, supra, pp. 226-227, e, infra, pp. 257-260. 
hace patente el menosprecio, ostensible «desde el prisma de cualquier observador razonable», por parte de la comunidad autónoma tanto de la propia fuerza de obligar de la Constitución a la que ciudadanos y poderes públicos quedan sujetos, como de un principio de lealtad constitucional que obliga a todos, concreción, a su vez, de un «deber general de fidelidad a la Constitución» que resulta «soporte esencial del funcionamiento del Estado autonómico y cuya observancia resulta obligada».

Se vincula así en la STC 89/2019 el supuesto del grave atentado al interés general con el principio de lealtad constitucional. Principio que se puede transgredir al ejercer las propias competencias, pues el mismo requiere que las decisiones tomadas por todos los entes territoriales tengan como referencia necesaria la satisfacción de los intereses generales y que, en consecuencia, no se tomen decisiones que puedan menoscabar o perturbar dichos intereses, de modo que esta orientación ha de ser tenida en cuenta, incluso, al gestionar los intereses propios.

\section{SOBRE LA CONSTRICCIÓN DE LA AUTONOMÍA}

Diferenciados los dos presupuestos que permitirían acudir al procedimiento del art. $155 \mathrm{CE}$, el TC considera que siempre que concurran aquellos, el referido precepto constitucional permite la constricción de la autonomía y, por lo mismo, la inaplicación excepcional de normas estatutarias y legales y su desplazamiento temporal.

El TC contrasta así el supuesto de control previsto en el art. $155 \mathrm{CE}$ con el resto de controles de vigilancia y supervisión de la actividad de las comunidades autónomas previstos en otros preceptos constitucionales, pues si bien en estos últimos la autonomía constitucionalmente garantizada es compatible con los controles sobre la actuación de aquellas, pues el ejercicio de las competencias propias de control del Estado no puede suponer nunca una sustitución en la definición autonómica de sus propias políticas en el ámbito de su competencia, el art. $155 \mathrm{CE}$ no responde a dicha lógica, ya que no se trata de un control de naturaleza competencial. En efecto, el TC señala que se trata del uso de la coerción estatal que da lugar a una injerencia en la autonomía de las comunidades autónomas, la cual quedará temporalmente constreñida, en mayor o menor grado, según la concreta situación lo requiera, en pro de la consecución de los fines para los que la norma fundamental autoriza dicha injerencia.

Así, por ejemplo, la sustitución por el Ejecutivo estatal de determinadas actuaciones o funciones de competencia autonómica, que no sería factible en 
las relaciones competenciales entre las comunidades autónomas y el Estado, sí lo es en el procedimiento instituido en el art. $155 \mathrm{CE}$, ámbito en el que órganos del Estado son llamados por la Constitución a limitar la autonomía, en mayor o menor medida, para garantizar la integridad del orden constitucional frente a contravenciones del mismo no reparables por las vías ordinarias de control.

El principio de autonomía no puede, por tanto, oponerse al de unidad -que es el que se busca salvaguardar con el procedimiento de coerción-, pues en realidad este último es el presupuesto necesario del primero y por ello la coerción estatal del art. 155 CE depara la constricción o limitación directa de la autonomía para salvaguardar la unidad, sin perjuicio, claro, de que esta coerción esté sometida a límites.

Es por ello por lo que el TC señala que el art. $155 \mathrm{CE}$ es, respecto de las normas del bloque de constitucionalidad relativas a la configuración de la autonomía y a la articulación de competencias entre el Estado y las comunidades autónomas, ley extraordinaria, y perdería esa condición si los límites a la autonomía a los que puede dar lugar su aplicación quedaran limitados por la invocación del régimen ordinario de aquella configuración institucional y de su articulación competencial.

Consecuentemente, la apreciación acerca de la validez o invalidez de las medidas adoptadas en aplicación de la coerción estatal ha de hacerse no por referencia a las normas que en el bloque de constitucionalidad delimitan la autonomía, sino atendiendo a la norma constitucional que permite excepcionar o desplazar aquellas normas, el propio art. $155 \mathrm{CE}$.

Puesto que no es posible oponer el bloque de la constitucionalidad al art. $155 \mathrm{CE}$, y puesto que el art. $155 \mathrm{CE}$ es una autorización para limitar el autogobierno en circunstancias extraordinarias, el TC subraya a continuación que no cabe incoar este procedimiento sino cuando, cumplidos los presupuestos, se esté ante una actuación autonómica ante la que no existan otras vías a través de las cuales se asegure el cumplimiento de la Constitución y las leyes o el cese del atentado al interés general. Para el TC se trata de un precepto cuya aplicación solo procede en circunstancias especialmente críticas.

\section{SOBRE LOS LÍMITES Y EL CONTROL JURISDICCIONAL DEL PROCEDIMIENTO DE COERCIÓN}

Al TC le corresponde controlar, en su función de intérprete supremo de la Constitución, el cumplimiento de los límites materiales y formales que, en su caso, deriven del art. $155 \mathrm{CE}$, esto es, controlar la adecuación a 
la Constitución del ejercicio del poder de coerción estatal. Sin embargo, la STC 89/2019 matiza como debe ser en la práctica el ejercicio de ese control.

En efecto, el TC diferencia entre los límites que deben ser tenidos en cuenta por aquellas instituciones encargadas de promover y ejecutar el procedimiento del art. $155 \mathrm{CE}$, el Senado y el Gobierno, y el control que de tales límites cabe esperar del TC, pues en este segundo caso opera un cierto self-restrain.

Así, al referirse a la doctrina general de los límites materiales al ejercicio del art. 155 CE, la STC 89/2019 apela a una serie de reglas y principios que son una suerte de aplicación de los pasos sucesivos del principio de proporcionalidad, aunque no se expliciten como tales. Cabe recordar que el principio de proporcionalidad conlleva, con carácter general, el planteamiento de tres juicios sucesivos (de idoneidad, de necesidad y de proporcionalidad en sentido estricto) que la doctrina constitucional ha aplicado sobre todo para controlar medidas limitativas de los derechos fundamentales. Con carácter previo a los juicios sucesivos referidos se hace necesario determinar la legitimidad del fin que se quiere alcanzar con la medida a adoptar.

Así, en esta línea, la STC 89/2019 recuerda que el art. 155 CE no es un fin en sí mismo, sino un instrumento para garantizar la validez y eficacia de la Constitución en aquellos supuestos en los que sea manifiesto que solo a través de esta vía es posible restaurar el orden constitucional. Evocación a que su uso solo podrá justificarse en la prosecución de una finalidad que sea legítima, como es el restablecimiento del orden constitucional.

A continuación la STC 89/2019 señala que las «medidas necesarias» que el art. $155 \mathrm{CE}$ permite aprobar y adoptar están condicionadas por lo que resulta de su tenor, en el sentido de que han de responder a la finalidad bien de obligar a la comunidad autónoma a cumplir con las obligaciones constitucionales y legales incumplidas, bien de preservar o proteger el mencionado interés general contra el que se ha atentado. Lo que no es sino la comprobación del principio de adecuación o idoneidad de las medidas, primer paso de una aplicación canónica del principio de proporcionalidad.

La STC 89/2019 subraya que el art. 155 CE no es el único modo de hacer cumplir a una comunidad autónoma sus obligaciones o de impedir que atente contra el interés general, pues es un procedimiento de carácter extraordinario en el sentido de que solo puede emprenderse cuando las vías generales o comunes de control, jurisdiccionales o no, hayan resultado insuficientes para restablecer el orden constitucional transgredido o así se prevea fundadamente que vaya a ser en atención ya a la actitud inequívocamente renuente de los mismos órganos superiores de la comunidad autónoma, ya a la propia entidad del ilícito de que se trate. Así, únicamente cabría acudir a esta vía, 
cumplidas sus demás condiciones, ante conculcaciones flagrantes del orden constitucional que, por su entidad, o por la actitud inequívoca de los órganos superiores de la propia comunidad autónoma, evidenciaran la insuficiencia de los medios ordinarios a través de los que se defiende, con normalidad, dicho orden. Lo que no es sino la comprobación del principio de necesidad de las medidas, segundo paso de una aplicación canónica del principio de proporcionalidad que exige la inexistencia de medidas menos restrictivas de la autonomía que permitan alcanzar con éxito la finalidad pretendida.

Y, finalmente, se establece una regla adicional, el art. $155 \mathrm{CE}$ permite la alteración temporal del funcionamiento del sistema institucional autonómico, pero en modo alguno puede dar lugar a la suspensión indefinida de la autonomía y, mucho menos, a la supresión institucional de la comunidad autónoma. No caben, por tanto, medidas tales como la derogación del estatuto de autonomía o la suspensión indefinida de esa misma autonomía. Por su propia naturaleza, atendiendo a la finalidad que este procedimiento persigue, ha de tener un límite temporal bien expresamente determinado o, como será lo más probable atendiendo a los supuestos que desencadenan su aplicación, determinable. El TC señala que el Senado ha de precisar en su propio acuerdo bien el término, bien la condición resolutoria de la intervención estatal, aun cuando esa fijación inicial quede a su apreciación en atención a las circunstancias y sin perjuicio de que las concretas medidas incluidas en el acuerdo pudieran ser objeto, llegado el caso, de prórroga o de renovación.

Sin embargo, una vez establecida la doctrina general de los límites del art. $155 \mathrm{CE}$, el TC se muestra deferente con aquellas instituciones encargadas de la aplicación de la coerción estatal en la apreciación que estas hagan de las sucesivas comprobaciones.

Así, en relación con las medidas a adoptar el TC afirma que se debe otorgar a los órganos constitucionales llamados a su aplicación un margen de necesaria discrecionalidad, pues la Constitución ha dejado en manos del Gobierno y, en última instancia, del Senado la determinación concreta de las medidas que procedan atendiendo a la situación que se trata de afrontar.

La aplicación de lo que se denomina «medio más benigno o menos gravoso» o del llamado por las representaciones procesales de la Generalitat de Cataluña criterio de "gradualidad» no puede ser empleada por el TC en el caso del art. $155 \mathrm{CE}$. De aceptar tales criterios, el TC ocuparía el lugar que la Constitución ha reservado en este procedimiento al Gobierno, para la propuesta, y al Senado, para la decisión final. Ambos deben realizar un determinado juicio de necesidad sobre las medidas que procedan, valoración que puede llegar a ser enjuiciada por el TC, si bien reconociendo el correspondiente margen de apreciación con que al efecto ha de contar la Cámara, dado 
que el análisis del TC no puede entrañar un juicio de intenciones políticas. Así, la necesidad de la medida deberá ser tenida en cuenta en la decisión del Senado, pero no puede considerarse como pauta para el enjuiciamiento del TC.

En esta línea, de acuerdo con la STC 89/2019, el concepto «medida necesaria» que emplea el art. 155 CE supone un límite jurídico que el TC ha de utilizar, para juzgar no la medida en sí, sino el juicio que han realizado otros órganos constitucionales, el Gobierno y el Senado, acerca de la adecuación de la medida a las circunstancias que han desencadenado la aplicación del art. 155 CE. En ese juicio externo es al TC, que es el garante de la supremacía constitucional, al que corresponde decidir si la valoración de la necesidad se ajusta o no a lo que exige el art. $155 \mathrm{CE}$, ejerciendo para ello su papel de intérprete de la definición de las categorías y conceptos constitucionales, sin sustituir el juicio político ni formular hipótesis sobre la viabilidad de otras alternativas.

Esto es, se trata de utilizar parámetros de constitucionalidad racionalmente aceptables, ponderados en atención a las circunstancias del caso, en función tanto de los hechos consumados como de otros previsibles, para valorar, con un canon de escrutinio externo, la razonabilidad del juicio acerca de la relación de las medidas acordadas con la finalidad de defender el orden constitucional frente a su patente transgresión por un poder público.

En este punto el juicio de necesidad que corresponde realizar al Gobierno y al Senado será controlado por el TC, pero lo hará a través de un escrutinio de mera razonabilidad del mismo, sin que le corresponda sustituir aquel ni formular hipótesis sobre la viabilidad de otras alternativas. Así, para la STC 89/2019, «juzgar sobre la "necesidad" o no de unas determinadas medidas aprobadas mediante este procedimiento supone apreciar si lo acordado en concreto por la cámara fue o no respuesta adecuada a las circunstancias", pero de la doctrina del TC parece desprenderse que no se tiene por qué entrar a juzgar si fue la más adecuada.

\section{SOBRE LAS MEDIDAS A ADOPTAR EN EL PROCEDIMIENTO DE COERCIÓN}

El art. 155.1 CE no especifica las medidas en las que puede materializarse la coerción estatal, pues elude tasar las que el Gobierno puede proponer y la Cámara Alta autorizar. Tampoco exige que las medidas aprobadas por el Senado hayan de ser necesariamente autoaplicativas, en el sentido de que no requieran ulteriores disposiciones y actos de aplicación. No cabe en abstracto restringir las modalidades de intervención coercitiva, pues el art. 155.1 CE 
permite tomar «las medidas necesarias», y el silencio o la apertura del precepto, al no enumerarlas o fijar su carácter, trata de facilitar su adaptación a los variables supuestos de incumplimiento de obligaciones constitucionales o legales o de atentados contra el interés general de España.

Por tanto, las posibles modalidades de la intervención coercitiva no se ciñen a la imposición de concretos deberes de hacer por el Senado sobre la comunidad autónoma, ni se agotan en la potestad gubernamental de impartir instrucciones vinculantes a las autoridades autonómicas. Debe subrayarse que entre las «medidas necesarias» pueden llegar a estar, en atención a las circunstancias, las de carácter sustitutivo mediante las que la Cámara apodere al Gobierno para i) subrogarse en actuaciones o funciones concretas de competencia autonómica, u ii) ocupar el lugar, previo desplazamiento institucional, de determinados órganos de la comunidad autónoma.

Esta sustitución no implica la supresión de la comunidad autónoma, pues esta subsiste como tal durante la intervención coercitiva, por más que puedan ser órganos estatales los que, a ciertos efectos, decidan por ella. No obstante lo cual, la STC 89/2019 advierte de que en el desempeño de unas $\mathrm{u}$ otras funciones de sustitución el Gobierno o las autoridades que al efecto pudiera llegar a designar quedarían siempre sujetos al deber de observar un comportamiento leal para con la comunidad autónoma así intervenida.

De interés es igualmente la puntualización del TC en relación con que las «medidas necesarias» a las que se refiere el apartado 1 del art. $155 \mathrm{CE}$ no pueden confundirse con las instrucciones a las que se alude en el apartado 2 del art. $155 \mathrm{CE}$, pues eso supondría un reduccionismo que agotaría el entendimiento de las medidas necesarias del art. 155.1 CE, en la impartición de las mencionadas instrucciones. Es más, para la STC 89/2019, las instrucciones y la potestad de impartirlas a que se refiere el art. 155.2 CE no son propiamente una medida, sino un excepcional instrumento jerárquico, previsto por la propia Constitución, puesto a disposición del Gobierno para conseguir ejecutar las «medidas necesarias» ya aprobadas por el Senado.

\section{SOBRE LOS ÓRGANOS INTERVINIENTES EN LA COERCIÓN}

A continuación, cabe destacar la doctrina que la STC 89/2019 establece en relación con los órganos intervinientes en el proceso de coerción.

Así, el art. 155 CE confiere a dos órganos la articulación del poder de coerción sobre las comunidades autónomas. Al Gobierno, al que le corresponde tanto iniciar el procedimiento mediante el previo requerimiento como, en su caso, la propuesta de las medidas que considere necesarias, y al Senado, 
al que incumbe la decisión final sobre si procede aprobar las medidas propuestas por el Gobierno y en qué términos.

El Gobierno adicionalmente es el que en su caso ejecuta las medidas autorizadas por el Senado, y cuando lo hace no actúa estrictamente como Poder Ejecutivo, en relación con el reparto horizontal de funciones entre el Legislativo y el Ejecutivo, sino como órgano constitucional garante de la integridad de la norma suprema del ordenamiento y del orden territorial que de ella deriva, y con la finalidad de reconducir la actuación de una comunidad autónoma cuyos órganos han infringido gravemente obligaciones constitucionales o legales o han atentado contra el interés general de España. No está, así, ejerciendo las facultades que le atribuye el art. $97 \mathrm{CE}$, sino las que específicamente le otorga el Senado a través del procedimiento previsto en el art. $155 \mathrm{CE}$.

El Gobierno habrá de actuar siempre sujeto a la legalidad, estatal o autonómica, que sea de aplicación en cada caso, siempre y cuando esa legalidad no haya resultado a su vez excepcionada o temporalmente innovada por el acuerdo del Senado. Se sigue de lo anterior que el Gobierno no puede quedar autorizado por el Senado para ejercer, en este procedimiento, las potestades legislativas ordinarias que corresponden ya a las Cortes Generales, ya al Parlamento autonómico. El Gobierno ha de actuar vinculado a lo dispuesto en el acuerdo del Senado y en el marco del mismo, y es también claro que las decisiones que el Gobierno adopte no están exentas del correspondiente control judicial.

Entre las eventuales medidas que el Senado puede autorizar para su adopción por el Gobierno, excluido que le corresponda el ejercicio ordinario de potestades legislativas, pueden incluirse aquellas que supongan una injerencia en la actividad del Parlamento autonómico, siempre que tales medidas sean temporales y, atendida la situación concreta planteada, puedan considerarse adecuadas para reconducir la actuación de la comunidad autónoma que ha dado lugar a la aplicación del art. $155 \mathrm{CE}$. Ello se fundamenta en que el acuerdo que puede aprobar el Senado tiene fuerza de ley, como corresponde a un acto parlamentario al que la Constitución apodera para constreñir, limitar o excepcionar, en el grado que sea, competencias autonómicas definidas en el bloque de constitucionalidad. En atención a esa misma eficacia, ese acuerdo senatorial puede acuñar para la ocasión reglas específicas que, circunstancialmente, aseguren la eficacia de su ejecución por el Gobierno y, con ello, la finalidad misma perseguida por el art. $155 \mathrm{CE}$. Reglas entre las que pueden incluirse aquellas que, de modo temporal, ordenen las condiciones y facultades de la acción del Gobierno en el marco del art. 155 CE y que pueden desplazar pro tempore otras normas del ordenamiento alterando, en lo necesario, el ordenamiento pero sin integrarse de modo estable en él. 
Establecida la doctrina general en relación con la coerción estatal, el TC procede a aplicarla a las concretas medidas adoptadas en el Acuerdo del Pleno del Senado, de 27 de octubre de 2017, y así, por ejemplo, rechaza que sea inconstitucional el cese del Govern y la sustitución de los cesados en el ejercicio de sus funciones por el Gobierno de la nación, pues señala que ante la evidencia de un Gobierno que ha provocado una grave crisis constitucional, con la proclamación de una «república catalana» (ficticia en derecho, pero afirmada y propugnada de facto) mediante la que se pretendía quebrar la unidad de la nación española, no pueden tacharse de excesivas las medidas autorizadas por el Senado para el cese y sustitución de quienes, si bien ostentaban aún los títulos respectivos de presidente y vicepresidente de la Generalitat de Cataluña y de miembros de su consejo de gobierno, actuaban como un mero poder de hecho. Para el TC las medidas en cuestión no incurrieron en inadecuación alguna, no siendo posible tacharlas de exorbitantes o desmedidas, en atención a las circunstancias valoradas entonces por la Cámara para estimarlas «necesarias».

Igualmente rechaza la inconstitucionalidad de la disolución del Parlament, pues, en el seno del procedimiento previsto en el art. 155 CE, el Senado puede autorizar al Gobierno para disolver una Asamblea autonómica, siempre que tal medida se presente como «necesaria», atendiendo a la situación creada. Lo que no podría en ningún caso es autorizarle para sustituir permanentemente a la Cámara autonómica en el ejercicio de sus funciones, pues el Gobierno no puede quedar apoderado para hacer las veces del legislador ordinario y tampoco tal sustitución podría correr a cargo de las Cortes Generales, que no están llamadas a intervenir en el ejercicio de la coerción estatal. Además, dicha sustitución permanente implicaría una suspensión indefinida del autogobierno, representado por el Parlamento, que no es posible en el seno del art. 155 CE.

La STC 89/2019, únicamente, estima la impugnación de la previsión del acuerdo del Senado que prevé la privación de efectos jurídicos a las disposiciones o actos publicados en el Diario Oficial de la Generalitat de Cataluña o en el Boletín Oficial del Parlamento de Cataluña sin la autorización o en contra de lo acordado por los órganos o autoridades creados o designados al efecto por el Gobierno de la nación. Esta previsión es declarada inconstitucional y nula por considerar el TC que la reacción ante una eventual publicación no autorizada o prohibida no puede ser, sin daño para la seguridad jurídica (art. 9.3 $\mathrm{CE})$, la de tener por ineficaz la publicación. La publicidad de las normas está expresamente garantizada por el art. 9.3 CE y resulta inseparable de la seguridad jurídica que el propio precepto constitucional preserva ${ }^{23}$.

23 Tomás de la Quadra-Salcedo Janini. 


\section{ORGANIZACIÓN DE LOS PODERES PÚBLICOS}

1. Sin duda los pronunciamientos más relevantes del TC durante el período considerado en esta crónica son las dos sentencias que resuelven los recursos de inconstitucionalidad interpuestos contra la aplicación del art. 155 CE a la comunidad autónoma de Cataluña.

La sentencia principal es la STC 89/2019 (Pleno), de 2 de julio ${ }^{24}$, que resuelve el recurso interpuesto por más de cincuenta diputados del Grupo Parlamentario Unidos Podemos. La STC 90/2019 (Pleno), de 2 de julio, que resuelve el recurso planteado por el Parlamento de Cataluña, resume y reitera la doctrina contenida en la STC 89/2019. Salvo en un limitado punto que se declara inconstitucional y nulo ${ }^{25}$, el TC desestima la impugnación del Acuerdo del Pleno del Senado de 27 de octubre de 2017, por el que se aprobaron las medidas requeridas por el Gobierno al amparo del art. $155 \mathrm{CE}$ como consecuencia de las gravísimas actuaciones llevadas a cabo por las instituciones de la Generalidad de Cataluña en el marco del proceso secesionista, muy particularmente por los hechos de los meses de septiembre y octubre de 2017. ${ }^{26}$

El art. $155 \mathrm{CE}$ incorpora a nuestro ordenamiento un instrumento de coerción estatal típico de los Estados federales. Así lo corrobora el TC, al precisar que el art. $155 \mathrm{CE}$ no responde a la lógica de un control de naturaleza competencial, como el que el bloque de constitucionalidad atribuye en determinados supuestos al Estado respecto de las comunidades autónomas, sino que se trata de la coerción estatal sobre las comunidades autónomas que

24 Véanse supra pp. 226-227 y 248-256.

25 El párrafo segundo del apartado E.3 del Acuerdo, en el que se sancionaba con la falta de vigencia de las normas y de validez y efectos de los actos, acuerdos o resoluciones que fueran publicados en el Diario Oficial de la Generalitat o en el Boletín Oficial del Parlamento de Cataluña sin autorización o en contra de lo acordado por los órganos o autoridades designados por el Gobierno de la nación. No consta que esta previsión llegara a aplicarse durante la vigencia del acuerdo impugnado.

26 El Gobierno de la Generalidad surgido de las elecciones autonómicas celebradas el 21 de diciembre de 2017 (convocadas por el presidente del Gobierno de la nación en aplicación del Acuerdo del Pleno del Senado de 27 de octubre de 2017) se personó y formuló alegaciones en ambos recursos de inconstitucionalidad. Previamente, el Gobierno de la Generalidad, antes de la destitución de sus miembros conforme a lo autorizado por el Acuerdo del Pleno del Senado de 27 de octubre de 2017, había intentado impugnar infructuosamente este acuerdo horas antes de su aprobación; el recurso de inconstitucionalidad fue inadmitido por ATC 142/2017 (Pleno), de 31 de octubre, reseñado en Revista Española de Derecho Constitucional, núm. 112, 2018, pp. 233-234. 
depara una injerencia en la autonomía, la cual quedará temporalmente constreñida en mayor o menor grado, según la concreta situación lo requiera, en pro de la consecución de los fines para los que la CE autoriza esa injerencia. El fin de la intervención o injerencia que el art. $155 \mathrm{CE}$ consiente «no puede ser otro que restablecer el orden constitucional y, con él, el normal funcionamiento institucional de la comunidad autónoma en el seno de dicho orden» (FJ 4).

Esa coerción estatal tiene carácter extraordinario, de modo que no resulta de aplicación ante cualquier incumplimiento por una comunidad autónoma de las obligaciones constitucionales o legales que le incumban, «sino cuando se esté ante una actuación autonómica que incumpla la Constitución $\mathrm{u}$ otras leyes o atente gravemente al interés general de España ante la que no existan otras vías a través de las cuales se asegure el cumplimiento de la Constitución y las leyes o el cese del atentado al interés general»; esto es, la aplicación del art. $155 \mathrm{CE}$ «solo procede en circunstancias especialmente críticas», en las que se pone de manifiesto «la grave alteración jurídica e institucional en parte del territorio nacional» (STC 89/2019, FJ 4), como en efecto se aprecia que ha sucedido en la comunidad autónoma de Cataluña, muy particularmente por las actuaciones que se sucedieron durante los meses de septiembre y octubre de 2017, evocadas con precisión por el TC (STC 89/2019, FJ 6). De lo anterior se sigue que, en buena medida, la coerción estatal regulada prevista en el art. $155 \mathrm{CE}$ tiene naturaleza subsidiaria. Así se afirma expresamente en la síntesis descriptiva que precede al encabezamiento de la STC 89/2019. No obstante, conviene advertir que el TC se cuida de precisar que lo anterior no significa que en todo caso sea necesario agotar las vías generales o comunes de control, jurisdiccionales o no, para aplicar el art. 155 CE: también cabría acudir a esta vía en caso de "conculcaciones flagrantes del orden constitucional que, por su entidad, o por la actitud inequívoca de los órganos superiores de la propia comunidad autónoma, evidenciaran la insuficiencia de los medios ordinarios a través de los que se defiende, con normalidad, dicho orden» (STC 89/2019, FJ 4). La regla, pues, será que la aplicación del art. 155 CE tendrá carácter subsidiario, como vía "de último recurso» (expresión ya utilizada por la STC 215/2014, FJ 8, que cita la STC 89/2019, FJ 4), a la que se acudirá si no han tenido éxito medidas menos restrictivas para el autogobierno, pero no cabe descartar la apelación «directa» a la vía del art. $155 \mathrm{CE}$ en los supuestos excepcionales que el propio TC señala.

En fin, y como corolario también de lo anterior, la coerción estatal prevista en el art. $155 \mathrm{CE}$ es de naturaleza temporal o provisional. La aplicación del art. $155 \mathrm{CE}$ «no puede dar lugar a una constricción o limitación de la autonomía indefinida en el tiempo", sino que, "por su propia naturaleza, 
atendiendo a la finalidad que este procedimiento persigue, ha de tener un límite temporal», que ha de ser establecido por el Senado, a partir de la propuesta del Gobierno. Exigencia que se cumple por el acuerdo impugnado (STC 89/2019, FJ 4). De hecho, cuando el TC procede a dictar sentencia ya se habían agotado o decaído en su vigencia todas las medidas discutidas en el proceso, lo cual no es óbice, claro está, para que el TC lleve a cabo el enjuiciamiento constitucional del acuerdo impugnado, que cuenta con "fuerza del ley» y es, por tanto, susceptible de control en vía de recurso de inconstitucionalidad (STC 89/2019, FJ 2) ${ }^{27}$.

La aplicación del art. $155 \mathrm{CE}$ exige dos requisitos procedimentales: el previo requerimiento del Gobierno de la nación al presidente de la comunidad autónoma para que cese en el incumplimiento o en la actuación contraria al interés general, $y$, en el caso de que el requerimiento no fuera atendido, la aprobación por el Senado, por mayoría absoluta, de las medidas coercitivas que estime oportunas a partir de la previa propuesta del Gobierno. El TC constata, con una fundamentación pormenorizada, que ambos requisitos procedimentales se cumplieron en el presente caso (STC 89/2019, FF. JJ. 5 a 9).

Por lo que se refiere al contenido de la coerción, el TC rechaza que la referencia del art. 155.1 CE a las "medidas necesarias» que el Senado puede autorizar, a propuesta del Gobierno, deba entenderse limitada a la imposición de obligaciones de hacer a la comunidad autónoma. Descarta igualmente que puedan confundirse tales medidas con las instrucciones a las que se alude en

27 Que el Acuerdo del Pleno del Senado que aprueba las medidas requeridas por el Gobierno al amparo del art. 155 CE tiene fuerza o valor de ley ya lo había anticipado el TC en el citado ATC 142/2017 (Pleno), de 31 de octubre. En cambio, los actos adoptados por el Gobierno de la nación, bien para la ejecución de las medidas autorizadas por el acuerdo del Senado, bien en sustitución del Gobierno de la Generalitat conforme a lo previsto en dicho acuerdo, «no tienen fuerza de ley, sino la propia de los actos aplicativos de una ley, y no pueden, en consecuencia, impugnarse a través del recurso de inconstitucionalidad», según señala la STC 90/2019, FJ 2a. Por tanto, esos actos del Gobierno pueden ser impugnados ante la jurisdicción contencioso-administrativa, como en efecto lo han sido en algunos casos, desestimados por diversas sentencias de la Sala de lo Contencioso-Administrativo del Tribunal Supremo (Sentencia núm. 252/2019, de 26 de febrero, que desestima el recurso interpuesto contra el Real Decreto 945/2017, de 27 de octubre, en relación con la supresión de DIPLOCAT; Sentencia núm. 277/2019, de 4 de marzo, que desestima el recurso interpuesto contra el Real Decreto 946/2017, de 27 de octubre, sobre disolución del Parlamento de Cataluña y convocatoria de elecciones, y Sentencia núm. 653/2019, de 21 de mayo, que desestima el recurso interpuesto contra el Real Decreto 942/2017, de 27 de octubre, en relación con la destitución del presidente de la Generalidad). 
el art. 155.2 CE. No cabe en abstracto restringir las modalidades de intervención coercitiva, que dependerán en cada caso de los variables supuestos de incumplimiento de obligaciones constitucionales o legales o de atentados contra el interés general de España. En suma, el art. 155 CE deja en manos del Senado, a partir de la propuesta del Gobierno, la determinación concreta de las medidas que procedan atendiendo a la situación que se trata de afrontar; se otorga así a los órganos constitucionales llamados a la aplicación del art. 155 CE un margen de necesaria discrecionalidad, concluye el TC (STC 89/2019, FJ 10). En consecuencia, el contenido de la coerción prevista en el art. 155.1 CE permite medidas muy incisivas, como la destitución de los miembros del Gobierno de la comunidad autónoma y la consiguiente sustitución en el ejercicio de sus funciones por los órganos o autoridades que a tal efecto cree o designe el Gobierno de la nación (STC 89/2019, FJ 12), así como la disolución anticipada de la Asamblea legislativa autonómica y posterior convocatoria de elecciones por el presidente del Gobierno (STC 89/2019, FJ 13), siempre que tales medidas se presenten como "necesarias», atendiendo a la situación creada por la comunidad autónoma, y que tengan, como se ha dicho, carácter provisional: el Senado no puede autorizar al Gobierno de la nación para sustituir permanentemente a la Cámara y al Gobierno autonómicos en el ejercicio de sus funciones (STC 89/2019, FJ 11). Ello supondría la disolución de la comunidad autónoma, lo que resulta vedado por la CE: la aplicación del art. 155 $\mathrm{CE}$ «permite la alteración temporal del funcionamiento del sistema institucional autonómico, pero en modo alguno puede dar lugar a la suspensión indefinida de la autonomía y, mucho menos, a la supresión institucional de la misma comunidad autónoma» (STC 89/2019, FJ 4).

2. También hemos de referirnos en este apartado a la STC 98/2019 (Pleno), de 17 de julio ${ }^{28}$, que declara inconstitucionales y nulos sendos incisos de la Resolución 92/XII del Parlamento de Cataluña, de 11 de octubre de 2018, en los que esta Cámara reprobaba al rey Felipe VI por su discurso del 3 de octubre de 2017, referido a los acontecimientos acaecidos en Cataluña en las fechas inmediatamente anteriores, particularmente los del día 1 de octubre, y se pronunciaba, asimismo, a favor de la abolición de la monarquía.

La STC 98/2019 considera que el análisis de ambos incisos debe hacerse de forma conjunta, porque su contenido guarda una inequívoca unidad de sentido, como sostenía el abogado del Estado en su impugnación. Ese análisis conduce al TC a declarar inconstitucionales los dos incisos de la resolución impugnada.

28 Véanse supra pp. 229-230. 
La sentencia expone el estatus constitucional del rey. Recuerda que «la monarquía parlamentaria deriva directamente de la Constitución, es configurada por ella y ha nacido del poder democrático del constituyente», esto es, que «la legitimidad de la monarquía trae causa de la Constitución». Así:

[...] el rey, como jefe del Estado, goza de una especial dignidad, pero no se sitúa jerárquicamente por encima de las instituciones, ni figura investido de potestades propias de supremacía para dictar decisiones vinculantes que se impongan a los poderes del Estado. Dispone de capacidad para promover o para perfeccionar iniciativas jurídicas (arts. 65 o $99.1 \mathrm{CE}$ ), pero no tiene posibilidad de adoptar por sí decisiones de poder o realizar los actos necesarios para su ejecución.

En suma, la configuración constitucional de la monarquía parlamentaria (art. 1.3 CE), "permite al rey, en cuanto titular de la Corona, ostentar una posición de auctoritas, pero no de potestas, con las salvedades que la Constitución le atribuye». Por otra parte, el rey, como jefe del Estado, es «una institución genuinamente estatal» (como ya destacó la STC 5/1987, de 27 de enero) y «ningún poder o institución autonómicos dispone de facultades o potestades de control político de los actos del jefe del Estado», que no interviene en la actividad ordinaria de las comunidades autónomas, al proyectarse siempre su actuación sobre un plano diferente, «a nivel de todo el Estado, en el ejercicio de las funciones que constitucionalmente le están asignadas». En fin, la CE establece la inviolabilidad y ausencia de responsabilidad del rey (art. 56.3 CE), debiendo sus actos ser siempre refrendados (art. $64 \mathrm{CE}$ ) y asumiendo la autoridad refrendante en cada caso la responsabilidad del acto del rey; de este modo, «la inviolabilidad de la persona del rey y la ausencia de responsabilidad por sus actos, con traslado de esta a las autoridades del Estado que los refrenden, constituyen un sistema específico de protección jurídica frente a cualquier tipo de injerencia».

Destaca asimismo la sentencia (FJ 4) que «el ordenamiento constitucional sitúa al rey como jefe del Estado y símbolo de la unidad y permanencia del Estado (art. 56.1 CE)», y que el rey, dentro del sistema de monarquía parlamentaria (art. 1.3 CE):

[...] se mantiene totalmente ajeno a toda controversia política, al margen de los diferentes poderes públicos y, por tanto, en un plano diferente al del resto de las instituciones del Estado (en el caso de autos, las autonómicas de Cataluña), no teniendo ninguna intervención en su normal desenvolvimiento, excepción hecha de los actos concretos en que se hace visible la inserción en el Estado de la organización institucional de la Comunidad Autónoma. 
Por lo que concluye, primeramente, que las afirmaciones de la Resolución parlamentaria impugnada de rechazo y condena al rey «son contrarias al art. 1.3 y $56.1 \mathrm{CE}$, que determinan el estatus constitucional del monarca». Además, «la decisión de la Cámara autonómica ha sido adoptada fuera del ámbito propio de sus atribuciones, que son las que le confieren la Constitución, el Estatuto de Autonomía de Cataluña y su propio reglamento orgánico, que no le reconocen ninguna potestad de censura o reprobación de los actos regios». Asimismo, teniendo en cuenta que la persona del rey es inviolable y está exenta de toda responsabilidad por sus actos (art. 56.3 CE), cualquier decisión institucional de un órgano público, en este caso del Parlamento de Cataluña, que pretenda censurar o reprobar al monarca «contraviene directamente el art. 56.3 CE, porque supone desconocer este estatus que la Constitución le reconoce al rey, al atribuirle una responsabilidad que es incompatible con su función constitucional $»^{29,30}$.

\section{DERECHOS FUNDAMENTALES}

1. En la STC 92/2019 (Sala Segunda), de 15 de julio, la queja en la que se fundamentaba el recurso de amparo era la lesión del art. $14 \mathrm{CE}$, como consecuencia de la regulación contenida en la regla tercera, letra c), del apartado primero, del texto refundido de la Ley general de la Seguridad Social, aprobado por el Real Decreto Legislativo 1/1994, de 20 de junio, en la redacción dada por el Real Decreto Ley 11/2013, de 2 de agosto, para la protección de los trabajadores a tiempo parcial y otras medidas urgentes en el orden económico y social ${ }^{31}$, cuya aplicación al caso determinó que las

29 El Parlamento de Cataluña no ha tardado en responder a la STC 98/2019, de 17 de julio. A propuesta una vez más de los grupos independentistas, el Pleno de la Cámara aprobó el 25 de julio de 2019 una nueva resolución (Resolución 534/XII, sobre las propuestas para la Cataluña real) en la que reafirma en sus mismos términos los pronunciamientos de la Resolución 92/XII que fueron anulados por la STC 98/2019. Contra esta nueva resolución el Gobierno ha promovido incidente de ejecución, habiendo acordado el TC dar traslado al Ministerio Fiscal y al Parlamento de Cataluña para formular alegaciones.

30 Herminio Losada González.

31 Según esa disposición, a los efectos del cálculo de la cuantía de la pensión, el período de cotización acreditado se obtiene aplicando el «coeficiente de parcialidad» — esto es, el porcentaje que representa la jornada realizada a tiempo parcial respecto a la efectuada por un trabajador a tiempo completo comparable - al número de días de 
resoluciones impugnadas denegasen al recurrente la pensión de jubilación en el porcentaje reclamado. El sistema de cálculo previsto legalmente es lo que se cuestionaba al considerar que vulneraba el derecho a la igualdad ante la ley, en tanto que, a diferencia de lo que ocurre con los trabajadores a tiempo completo, respecto de los cuales cada día completo trabajado equivale a un día cotizado, en el caso de los trabajadores a tiempo parcial el período de cotización se ve reducido por la aplicación del «coeficiente de parcialidad» que transforma los días trabajados a tiempo parcial en días teóricos de cotización. Este problema, recuerda el TC, fue recientemente resuelto por la STC 91/2019, de 3 de julio $^{32}$, en la que, dando respuesta a la cuestión interna de inconstitucionalidad planteada y en línea con las conclusiones previamente alcanzadas por el Tribunal de Justicia de la Unión Europea, se ha declarado la inconstitucionalidad y nulidad de la disposición adicional séptima de la LGSS en el aspecto aquí controvertido (aplicación del "coeficiente de parcialidad» sobre el período de cotización a los efectos del cálculo de la cuantía de la pensión de jubilación) por vulneración del art. $14 \mathrm{CE}$, no solo por establecer una diferencia de trato irrazonable sino también por incurrir en una discriminación indirecta por razón de sexo. En efecto, la STC 91/2019 ha considerado, con carácter general, que la norma cuestionada vulneraba el derecho a la igualdad ante la ley por cuanto que no existía una justificación objetiva y razonable para que el cálculo del período de cotización se realizase de modo distinto según se tratase de trabajadores a tiempo completo (en función del tiempo real cotizado) o de trabajadores a tiempo parcial (aplicando al tiempo cotizado un valor reductor). De este modo, con el método de cálculo implementado se impedía que, en la generalidad de los casos, los trabajadores a tiempo parcial no pudiesen obtener la pensión de jubilación en su porcentaje máximo, pues para ello resultaba preciso alcanzar un porcentaje de parcialidad elevado, castigando, de ese modo, a los trabajadores con menos porcentaje de parcialidad a lo largo de su vida laboral, esto es, a "quienes conforman el eslabón más débil del mercado de trabajo». Además, a la vista de que el porcentaje de mujeres que desempeñaban un trabajo a tiempo parcial en el mercado laboral era claramente superior al de los hombres, la citada STC 91/2019 apreció, asimismo, que la norma controvertida incurría en una discriminación indirecta por razón de sexo, habida cuenta que la aplicación del «coeficiente de parcialidad» generaba una diferenciación que no solo conducía «a un resultado perjudicial en

alta con contrato a tiempo parcial, y al resultado así obtenido se le aplica el coeficiente multiplicador del 1,5.

32 Véanse supra pp. 231 y 238. 
el disfrute de la protección de la Seguridad Social para los trabajadores contratados a tiempo parcial, sino que afecta[ba] predominantemente a las mujeres trabajadoras». Pues bien, explica el TC que aunque en el presente recurso de amparo no se planteaba un problema de discriminación por razón de sexo, sino que se denuncia únicamente el resultado perjudicial que a la parte recurrente la ha supuesto la aplicación del "coeficiente de parcialidad» en el cálculo de su pensión de jubilación, la anterior declaración de inconstitucionalidad implica, sin necesidad de razonamientos adicionales, la estimación del recurso por vulneración del derecho a la igualdad ante la ley.

2. En la STC 56/2019 (Sala Primera), de 6 de mayo, según el demandante de amparo, la Administración habría vulnerado su derecho al cargo (art. 23.2 CE) y a la integridad moral (art. 15 CE), en relación con el reconocimiento constitucional de la dignidad de la persona, por haberle sido asignado un puesto de trabajo exclusivamente formal o aparente, sin funciones definidas; por mantenerle durante largo tiempo completamente desocupado y sin información sobre sus atribuciones y por hacer caso omiso de sus reiteradas peticiones de tareas o traslación de destino y archivar su denuncia de acoso laboral ${ }^{33}$. Considera el TC que una situación como la sufrida por el recurrente

33 Recuerda el TC que son hechos acreditados e indiscutidos los siguientes: 1) el Ministerio del Interior creó un nuevo puesto de «vocal asesor» en la Gerencia sin definición de un ámbito de atribuciones para adjudicarlo al actual demandante de amparo; 2) la Administración le mantuvo durante largo tiempo (año y medio, aproximadamente) completamente desocupado, sin información sobre sus funciones, sin asignarle tareas y sin convocarle a reunión de trabajo alguna, situación que no padecieron los demás funcionarios de la entidad, que tenían atribuidas tareas específicas y despachaban individualmente con el secretario general de la entidad; 3) en múltiples ocasiones el demandante de amparó solicitó sin éxito ante el secretario general de la Gerencia y el secretario de Estado de Seguridad la asignación de responsabilidades o su traslado a otro destino (constan en las actuaciones varios escritos formales y correos electrónicos; también el testimonio de varios funcionarios sobre las constantes quejas del actor); 4) al persistir la situación de inactividad que venía padeciendo y al resultar infructuosos los intentos efectuados de que le fueran encomendadas tareas o para ser destinado a otro puesto, el demandante denunció su situación conforme al protocolo antes mencionado, cuyo anexo II atribuye la consideración de conducta "típica» constitutiva de acoso laboral a todas las consistentes en «dejar al trabajador de forma continuada sin ocupación efectiva, o incomunicado, sin causa alguna que lo justifique», y 5) el subsecretario de Interior, mediante Resolución de 10 de febrero de 2015, archivó la denuncia formulada, no porque la prolongada postergación laboral descrita fuera incierta, sino porque, según el informe de valoración inicial de los 
no afecta propiamente al derecho de los ciudadanos a «acceder en condiciones de igualdad a las funciones y cargos públicos, con los requisitos que señalen las leyes» (art. 23.2 CE), sino, en su caso, a derechos derivados del Estatuto del empleado público, por lo que descarta la afectación del mencionado artículo constitucional. No obstante, entiende que, a la vista de las sentencias impugnadas, la inactividad laboral prolongada a la que fue sometido el demandante de amparo involucra inequívocamente su derecho fundamental a la integridad moral y la prohibición de tratos degradantes (art. $15 \mathrm{CE}$ ); ahora bien, para valorar si la Administración ha vulnerado el derecho fundamental a la integridad moral de un empleado público hay que determinar, atendiendo a las circunstancias del caso, si la conducta enjuiciada es deliberada o, al menos, está adecuadamente conectada al resultado lesivo; si ha causado a la víctima un padecimiento físico, psíquico o moral o, al menos, encerraba la potencialidad de hacerlo, y si respondió al fin de vejar, humillar o envilecer o era objetivamente idónea para producir o produjo efectivamente ese resultado. Aprecia el TC, en primer término, que la inactividad profesional del recurrente no ha sido accidental. La Administración, si no quiso propiciarla desde el principio, pretendió, al menos, una vez producida, mantenerla y prolongarla. Recuerda que son hechos probados a este respecto que la Administración creó un puesto de trabajo sin contenido efectivo a fin de asignarlo al demandante de amparo y que, pese a las reiteradas quejas y peticiones de este, no intentó, siquiera mínimamente, poner remedio a la situación de inactividad laboral continuada. Resulta igualmente indicativa, explica la sentencia, la diferencia en el trato dispensado al demandante de amparo, pues los funcionarios restantes eran oportunamente convocados a reuniones de trabajo y disfrutaron de su correspondiente ámbito de atribuciones. En suma, concluye el TC afirmando que hay un amplio panorama indiciario inequívocamente revelador del carácter intencional, no casual, de la prolongada inactividad profesional padecida por el recurrente. A la vista de todo ello, atendidas las circunstancias del caso

instructores, falta la violencia psicológica por hostigamiento que, en su concepto, presupone toda conducta de acoso laboral; y el denunciante, aunque nunca pudo despachar individualmente con el secretario general en el edificio de la Gerencia - a diferencia de los demás funcionarios_-, pudo al menos dar su opinión en una cafetería cercana durante los descansos. El informe hace referencia igualmente a la dificultad de asignar un puesto después de las elecciones generales, cuando son muchos los funcionarios que solicitan la reincorporación al servicio activo al cesar en destinos habilitados para servicios especiales, como la dirección del gabinete del presidente del Consejo de Estado que ocupaba el denunciante. No obstante, reconoce que ello no puede justificar que se mantenga sin ocupación a un funcionario. 
(singularmente, la larga duración de la postergación laboral y la ausencia de motivo legítimo), concluye que la Administración dispensó al demandante de amparo un trato sin duda merecedor de la calificación de degradante $y$, en cuanto tal, contrario a su derecho fundamental a la integridad moral.

3. En la STC 62/2019 (Pleno), de 7 de mayo, se aborda la resolución de la Sala de lo Penal del Tribunal Supremo que acordó la prisión provisional del recurrente por hechos presuntamente constitutivos de delito de rebelión, al apreciar la concurrencia de riesgos de reiteración delictiva y fuga del procesado. El recurso de amparo se dirigía contra las resoluciones que declararon al demandante de amparo procesado por delito de rebelión y denegaron su petición de libertad provisional; los motivos principales del recurso se centraban en la vulneración del derecho a la libertad personal (art. 17.1 CE), en relación con el derecho a un juez imparcial y el derecho de defensa (art. 24.2 CE), por cuanto los autos sustentaron la prisión provisional en fines distintos a los aducidos por el Ministerio Fiscal, y en la vulneración del derecho a la libertad personal, por falta de fundamentación de la decisión de prisión provisional y por ausencia de ponderación de la vinculación de los hechos con la libertad de expresión y los derechos de reunión y manifestación (arts. 20.1.a y $21 \mathrm{CE}$ ). La queja nuclear se refería a la valoración del riesgo de fuga que, respecto del recurrente, fue novedosamente apreciada en el auto de procesamiento por un motivo que no fue, sin embargo, invocado por el fiscal en la comparecencia celebrada para resolver sobre la adopción de esa medida cautelar. Entiende el TC que ninguna tacha de inconstitucionalidad cabe reprochar a las resoluciones impugnadas, puesto que el órgano judicial no queda necesariamente constreńido por los fines que las partes acusadoras invoquen en su solicitud de prisión provisional. Por lo que se refiere a la censura fundada en la insuficiente fundamentación sobre el presupuesto de la prisión provisional, entiende el TC que los órganos judiciales sí ponderaron de manera individualizada la participación que tuvo en los hechos, y se evidencia que expusieron con detalle la secuencia fáctica en la que intervino el demandante de amparo. Tampoco estima la denunciada lesión que se anudaba a la calificación jurídica de los hechos que se atribuyeron al demandante. Considera el TC que en el auto de procesamiento se describe el comportamiento llevado a cabo por el recurrente y, a su vez, se argumenta sobre la calificación jurídico-penal de la que, indiciariamente, es tributaria esa conducta, y dicha resolución no incurre en los vicios de irrazonabilidad o arbitrariedad que darían lugar a la vulneración del derecho a la libertad reconocido en el art. 17.1 CE. En relación con la queja relativa a la genérica e insuficiente motivación de las resoluciones judiciales respecto de la apreciación de los riesgos de reiteración delictiva y fuga, así como la ausencia de ponderación de la proporcionalidad de 
la medida y sus circunstancias personales, señala el TC que la resolución impugnada cumple con las exigencias constitucionales de motivación y ponderación. En cuanto al peligro de fuga que novedosamente apreció el magistrado instructor, el recurrente también plantea objeciones de fondo; sin embargo, constata el TC que, para la acreditación de ese riesgo, los órganos judiciales tuvieron en cuenta la conjunción de dos factores con predicamento en la doctrina constitucional: que el dictado del auto de procesamiento supuso el afianzamiento de los indicios de criminalidad inicialmente apreciados y la mayor cercanía temporal del juicio oral, a causa del avance del procedimiento penal. Por último, en cuanto a la queja que suscita el demandante para sustentar la vulneración de su derecho a la libertad, concretamente referida a la falta de ponderación del ejercicio de los derechos fundamentales de reunión, manifestación y libertad de expresión, en relación con los hechos determinantes de la prisión provisional, afirma el TC que la garantía del derecho a la libertad no precisa de la ponderación que reclama el recurrente respecto del «efecto desaliento» en el ejercicio de los derechos fundamentales. Si así fuera, el órgano judicial se vería compelido a valorar aspectos que, si bien se armonizan con la función de dirimir sobre la responsabilidad penal del afectado, tales como la necesidad y proporcionalidad de la sanción penal, sin embargo, resultan extraños a los fines y principios inherentes a la prisión provisional, en la cual la reglas de necesidad y proporcionalidad presentan una dimensión diferente, dado su marcado carácter instrumental al que se ha hecho mención.

4. En la STC 55/2019 (Sala Segunda), de 6 de mayo ${ }^{34}$, el recurso de amparo se planteó contra dos resoluciones del letrado de la Administración de Justicia de la Sala de lo Social del Tribunal Supremo que resolvieron tener por no presentado el escrito de impugnación del recurso de casación para la unificación de doctrina, remitido a través del sistema Lexnet por el representante procesal de la recurrente, al haber incurrido este en un error al cargar los datos del formulario normalizado que debe cumplimentarse en dicha plataforma para el correspondiente envío del escrito. A tales resoluciones se achaca la vulneración del derecho a la tutela judicial efectiva (art. 24.1 CE), en su vertiente de acceso a los recursos. Destaca el TC que el recurrente impugna dos resoluciones dictadas por el letrado de la Administración de Justicia: una diligencia de ordenación y un decreto que denegó el recurso de reposición promovido contra aquella, y no resoluciones judiciales. La causa de que así sea es que en el momento en que se notificó aquel decreto no le era posible a la parte interponer contra él un recurso de revisión — ni cualquier otro tipo de recurso- ante la

34 Véanse supra pp. 235-236. 
sala competente, a fin de permitir su control jurisdiccional; lo impedía la dicción del entonces vigente art. 188.1, párrafo primero, de la Ley 36/2011, de 10 de octubre, reguladora de la jurisdicción social, al tratarse de un decreto que no ponía fin al procedimiento ni impedía su continuación ${ }^{35}$. Recuerda el TC su doctrina y las circunstancias del caso y considera que la demanda de amparo ha de ser estimada al apreciarse la vulneración del derecho a no padecer indefensión de la recurrente, ya que la demanda ha reconocido que al rellenar su representante procesal el formulario normalizado para la transmisión electrónica por Lexnet cometió un error al seleccionar el código del procedimiento, si bien da una explicación en su descargo al no venir indicadas de modo completo cada una de las dos modalidades de casación (la del régimen común, y la casación para la unificación de doctrina), lo que le hubiera permitido saber que solo podía elegir una de ellas, cuando parecía en cambio que debía pulsar las dos para formar toda la frase ("casación» y «unificación de doctrina»). No considera el TC irrelevante la circunstancia de que el sistema no sea del todo claro y pueda inducir a esa confusión, así como que en casos de simple error en los datos del formulario este no genere ningún aviso que dé margen a la persona para subsanarlo. Recuerda que el formulario normalizado cumple un papel accesorio de facilitación de la comunicación electrónica pero no deviene condicionante de la validez del escrito procesal remitido; es el escrito de impugnación del recurso de casación redactado y cargado en Lexnet el que debía ser examinado por la secretaría de la sala, en orden a dilucidar si permitía tenerlo por recibido y unirlo a las actuaciones de uno de sus procedimientos. Las resoluciones impugnadas dictadas por el letrado de la Administración de Justicia de la sala competente sostuvieron que no es válida la presentación del escrito, acordando incluso su devolución al conferir un carácter esencial e insubsanable al dato erróneo consignado en el formulario normalizado, en detrimento del análisis que resultaba exigible del propio contenido del escrito procesal.

35 Precisamente tal circunstancia determinó que esta Sala Segunda del TC, mediante ATC 20/2018, de 5 de marzo, elevara cuestión interna de inconstitucionalidad al Pleno respecto del precepto indicado, por su posible contradicción con el derecho a la tutela judicial efectiva (art. 24.1 CE), en su vertiente de acceso al recurso, atendida su similitud sustancial con el art. 102 bis.2, párrafo primero, LJCA, que había sido declarado inconstitucional y nulo por este motivo por la STC 58/2016, de 17 de marzo. Al haberse estimado la cuestión interna de inconstitucionalidad que aquí nos ocupa por la STC 72/2018, de 21 de junio, haciendo aplicación de la doctrina sentada por aquella STC 58/2016, y confirmada, por tanto, la imposibilidad legal que tenía la aquí recurrente para impetrar un control judicial de las resoluciones procesales del letrado de la Administración de Justicia dictadas, han de considerarse estas últimas correctamente recurridas en amparo. 
Semejante decisión ocasionó la vulneración del derecho de la demandante de amparo a no sufrir indefensión.

En la STC 93/2015 (Sala Segunda), de 15 de julio, el objeto de los recursos de amparo era determinar si los decretos de la letrada de la Administración de Justicia dictados en el expediente de jura de cuentas podían ser o no objeto de recurso de revisión o subsidiariamente de incidente de nulidad de actuaciones ante el juzgado que resolvió el litigio del que dichos honorarios traían causa, considerando la recurrente que la denegación del acceso a aquellos lesiona el art. 24.1 CE, al impedir la revisión jurisdiccional de lo acordado. Se remite el TC a las STC 49/2019, de 8 de abril, y STC 34/2019, de 14 de marzo $^{36}$, recordando que el debate de constitucionalidad que se plantea en esta tipología de casos afecta al régimen de recursos contra los decretos de los letrados de la Administración de Justicia en las reclamaciones de honorarios de abogados reguladas en la Ley de enjuiciamiento civil, en la medida en que pudiera eventualmente impedirse con esa normativa que las decisiones de aquellos letrados sean revisadas por los jueces y tribunales, titulares en exclusiva de la potestad jurisdiccional, vedándoles que dispensen la tutela judicial efectiva sin indefensión que garantiza el art. 24.1 $\mathrm{CE}^{37}$. En lo que afecta a las cuestiones planteadas, se remite a lo dicho en la STC 34/2019, que se fundamentó, en suma, en la existencia de un espacio de inmunidad jurisdiccional incompatible con las exigencias del derecho a la tutela judicial efectiva, que priva a las partes, dada la ausencia de recurso contra el decreto del letrado de la Administración de Justicia, de instrumentos indispensables para la defensa de sus derechos e intereses legítimos, como ocurre con su derecho a que dicha decisión procesal sea examinada y revisada por quien está investido de jurisdicción, esto es, por el juez o tribunal. Esa doctrina llevó al TC, en la STC 49/2019, de 8 de marzo, a estimar un recurso de amparo que planteaba una problemática del todo asimilable a la que se suscita en estos recursos acumulados.

5. En la STC 97/2019 (Pleno), de 16 de julio, el ahora recurrente en amparo fue condenado como autor de dos delitos de defraudación fiscal, al

36 Reseñadas en Revista Española de Derecho Constitucional, núm. 116, 2019, pp. 264-265.

37 Recuerda también el TC que en las SSTC 58/2016, de 17 de marzo, y 72/2018, de 21 de junio, declaró inconstitucionales y nulos el primer párrafo del art. 102 bis. 2 de la Ley 29/1998, de 13 de julio, reguladora de la jurisdicción contencioso-administrativa, en la redacción dada por la Ley 13/2009, y el art. 188.1, párrafo primero, de la Ley 36/2011, de 10 de octubre, reguladora de la jurisdicción social, respectivamente. 
haber ocultado a la hacienda pública la existencia de diversos fondos y activos de su titularidad en las cuentas de un banco suizo. El órgano judicial de primera instancia estimó como prueba lícita y suficiente de cargo la denominada «lista Falciani»; esto es, la información económica de la que se había apoderado sin autorización un trabajador del banco y que fue hallada por las autoridades francesas en el registro de su domicilio, siendo posteriormente entregada a la Agencia Tributaria española. Interpuesto recurso de casación, la Sala de lo Penal del Tribunal Supremo rechazó la alegada exclusión probatoria de la lista en cuestión, pese a su obtención por el Sr. Falciani sin autorización y con vulneración del derecho fundamental a la intimidad del demandante en amparo. El TC deniega el amparo por no concurrir la necesidad de extender la tutela del derecho a la intimidad del recurrente al ámbito del proceso penal. Explica que ni la legislación procesal ni la doctrina constitucional imponen una declaración automática de vulneración del derecho a un proceso con todas las garantías (y, en este caso, a la presunción de inocencia) cuando se constata la violación de un derecho sustantivo en la obtención de la prueba. La interpretación de la regla de exclusión probatoria y el consiguiente juicio de ponderación realizados por la Sala de lo Penal del Tribunal Supremo resultan compatibles con los derechos procesales aducidos en amparo. Por un lado, la proveniencia — pública o privada — de la vulneración del derecho a la intimidad del recurrente no altera el canon de constitucionalidad aplicable desde la óptica del derecho a un proceso con todas las garantías. Por otro, ni la índole y las características ni el resultado de la vulneración originaria del derecho sustantivo exigen una tutela adicional de la intimidad del recurrente, ya que su garantía corresponde a los tribunales penales o civiles existentes en el país en que se ha cometido la intromisión ilegítima. Además, los datos bancarios son aspectos periféricos de la llamada «intimidad económica», pesando sobre el obligado tributario el deber jurídico de aportarlos a la hacienda pública.

En la STC 83/2019 (Sala Primera), de 17 de junio, el demandante —detenido policialmente- dirigía su petición de amparo frente al auto por el que el juzgado de instrucción elevó la detención a prisión provisional, comunicada y sin fianza. En su recurso de amparo aducía, principalmente, que fue privado del derecho a acceder a los materiales del expediente necesarios para articular una adecuada defensa frente a la privación de libertad (arts. 24.2 y 17.1 y 3 CE); además, con fundamento en el art. 7 de la Directiva 2012/13/ UE, estimaba que el derecho de acceder a los elementos de las actuaciones esenciales para impugnar la legalidad de la privación de libertad no puede quedar constreñido por el secreto sumarial. Recuerda el TC su doctrina sobre la publicidad de las actuaciones judiciales, afirmando que el derecho a un 
proceso público en materia penal es garantía del justiciable frente a una justicia secreta que escape a la fiscalización del público, por ello el secreto, como instrumento preordenado a asegurar el éxito de la investigación penal, ha de emplearse con cautela evitando todo exceso, tanto temporal como material, alejado de lo imprescindible. En el caso examinado fue suprimido de la versión que le fue notificada al recurrente el fundamento jurídico de la resolución judicial que acordó su prisión provisional y que expresaba las fuentes de prueba de las que se desprendían los indicios de delito y aquellos riesgos que llevaron a adoptar dicha medida cautelar. No obstante, el núcleo de la lesión de derechos se situaba en la demanda en un escenario procesal anterior: la comparecencia que precedió a la adopción de la medida cautelar, momento en el que el demandante cuestionó por medio de su letrado que, por razón del secreto sumarial, pudiera obstaculizársele todo acceso a los materiales del procedimiento, impidiendo así que adquiriera conocimiento de lo esencial para impugnar la privación de libertad interesada por el Ministerio Fiscal. Recuerda el TC, sobre un problema similar, las SSTC 13/2017, de 30 de enero, y 21/2018, de 5 de marzo, pero considera que en el presente caso se trata de un contexto procesal diferente, cual es el alcance constitucional de los derechos a ser informado y a acceder a aquellos elementos de las actuaciones que resulten esenciales para impugnar la legalidad de la privación de libertad cuando, encontrándose la causa bajo secreto sumarial, el detenido ha pasado a disposición judicial y corresponde decidir sobre su situación personal, convocándose a tal fin la comparecencia del art. 505 LECrim. Al trasvasar al ámbito interno la Directiva 2012/13/UE, las Leyes Orgánicas 5/2015, de 27 de abril, y 13/2015, de 5 de octubre, dieron nueva redacción a algunos de los derechos que asisten al investigado (art. 118 LECrim) y al detenido o preso (art. 520.2 LECrim $)^{38}$. Del catálogo de derechos que se reconocen al detenido o privado de libertad, destaca el TC dos: el derecho a ser informado del procedimiento por medio del cual puede impugnar la legalidad de su detención, y el

38 Así, en relación con el primero se recuerda el derecho del investigado a ser informado de los hechos que se le atribuyan, así como de cualquier cambio relevante en los mismos o en el cuerpo de la investigación, con el grado de detalle suficiente como para permitir un efectivo ejercicio del derecho de defensa (art. 118.1.a LECrim), debiendo acomodar el lenguaje en que se facilita esta información a la edad, grado de madurez, discapacidad o cualquier otra circunstancia personal del interesado (arts. 5 y 6 $\mathrm{CEDH})$. Junto con él, aparece el derecho a examinar las actuaciones con la debida antelación para salvaguardar el derecho de defensa al que alude la directiva, que en todo caso tendrá que poder ejercitarse con anterioridad a que se le tome declaración (art. 118.1.b LECrim). 
derecho a acceder a los elementos de las actuaciones que sean esenciales para impugnar la legalidad de la detención o privación de libertad. Considera el TC que el pleno disfrute de estos derechos puede verse comprometido en su concurrencia con la declaración de secreto sumarial. Así lo reconoce la Directiva 2012/13/UE cuando justifica la exclusión judicial del derecho de acceso al expediente en caso de riesgo cierto de verse perjudicada la investigación penal en curso, entre otros motivos ${ }^{39}$. Afirma el TC que el trámite de audiencia vinculado a la adopción sobre el investigado de la medida cautelar de prisión provisional o bien de libertad provisional bajo fianza no es una formalidad irrelevante. El TC estima que, con carácter general, corresponde al juez instructor velar para que el detenido, una vez que se encuentra a su disposición, sea debidamente informado de sus derechos y garantías procesales. El sentido constitucional de estos derechos lleva a interpretar que, desde el momento en que el órgano judicial haya informado de que se va a celebrar la comparecencia, estará habilitado el investigado para expresar, por sí o a través de su abogado, su voluntad de acceder al expediente con la finalidad de tomar conocimiento de lo necesario para rebatir la procedencia de las medidas cautelares privativas de libertad que puedan interesar las acusaciones. Y ello porque ha de ser con anterioridad a que el órgano judicial adopte una decisión sobre la libertad del investigado cuando este, potencialmente afectado por la medida cautelar, tenga la oportunidad de requerir ese acceso al expediente que le permita disponer de aquellos datos que, como consecuencia de las diligencias practicadas, puedan atraer una valoración judicial última de pertinencia de la medida cautelar privativa de libertad que se solicite, conforme a los fines que la justifican. Recuerda el TC que, si bien el secreto sumarial incide, siquiera temporalmente, en las capacidades de defensa del investigado, limitando sus posibilidades de conocer e intervenir en el desarrollo de la investigación penal, ello no exime, sin embargo, de la obligación de informarle debidamente sobre los hechos que se le imputan y sobre las razones motivadoras de su privación de libertad. Tampoco puede privarle, en términos absolutos, de su derecho de acceder a las actuaciones para cuestionar e impugnar la legalidad de la privación de libertad; por ello, determinados por el instructor

39 El legislador nacional ha adicionado, no obstante, una singularidad respecto del investigado que se encuentra privado de libertad, de manera que el secreto sumarial se entenderá «sin perjuicio de lo previsto en el párrafo segundo del apartado tercero del artículo 505» (art. 302 in fine LECrim), con arreglo al cual «el abogado del imputado tendrá, en todo caso, acceso a los elementos de las actuaciones que resulten esenciales para impugnar la privación de libertad del investigado o encausado» (art. 505.3 LECrim). 
los elementos fundamentales del caso en clave de privación de libertad, la efectividad de la garantía requiere que la información se suministre al interesado por el mecanismo que resulte más idóneo, a criterio del órgano judicial. No basta, por tanto, con la información que verbal y genéricamente pueda proporcionarse en tal sentido. De conformidad con la doctrina expuesta, concluye el TC que debe entenderse lesionado el derecho del demandante a recibir en aquel momento conocimiento de lo esencial en las actuaciones para impugnar la medida cautelar de prisión provisional que instantes antes había interesado el Ministerio Fiscal, pues no se le dio acceso alguno a aquellos materiales de la investigación para poder rebatir los argumentos expuestos de contrario. En similar sentido, las SSTC 94 y 95/2019, de 15 de julio.

En la STC 61/2019 (Sala Primera), de 6 de mayo, la demanda de amparo se dirigía contra la sentencia que condenó a la recurrente en amparo como autora de un delito leve de estafa. Se aducía que dicha resolución vulneró el principio de proscripción de la indefensión (art. 24.1 CE) y el derecho a la presunción de inocencia (art. 24.2 CE) de la recurrente, al sostener que el escrito de alegaciones de la defensa no iba acompañado de documentación que le sirviera de soporte probatorio. La demandante afirmaba que su letrado, acogiéndose a lo previsto en el art. 970 de la Ley de enjuiciamiento criminal para los juicios por delito leve, intentó remitir la víspera del juicio el escrito de alegaciones de defensa y documentación complementaria por el sistema oficial de comunicaciones de la Administración de Justicia, Lexnet, lo que no fue posible por razones técnicas — al menos en lo que se refiere a la documentación-, si bien tras ponerse en contacto con la oficina judicial por teléfono se remitió dicha documentación al fax del juzgado. La indefensión alegada en la demanda se refiere tanto a la mutilación de las facultades alegatorias y de prueba que se siguieron para la demandante de amparo por el defectuoso funcionamiento de la oficina judicial como a la omisión de valoración judicial de dicha prueba, que a su entender redundaría en vulneración de su derecho a la presunción de inocencia por lo concluyente de su contenido. Constata el TC que el juzgado de instrucción afirmó en su sentencia que la documentación de descargo anunciada en el escrito de alegaciones no había sido aportada. Esta documentación, sin embargo, obraba en la oficina judicial, pues figura unida a las actuaciones y, aunque no es posible determinar el momento de su incorporación, sí consta que fue remitida al fax del juzgado con anterioridad a la celebración del juicio. Analiza el TC si la ausencia de la prueba de descargo en el expediente judicial se debió a una acción u omisión achacable al órgano judicial, y si se trata de una prueba que por su contenido hubiera tenido virtualidad para modificar el sentido del fallo. En relación con la primera cuestión excluye cualquier tipo de pasividad o negligencia de la demandante de amparo 
habida cuenta de que están acreditados los intentos de su letrado por hacer llegar al juzgado las alegaciones y documentos acreditativos, mientras que el juzgado no desplegó la misma diligencia. El TC considera, además, que se produjo una merma relevante de las facultades probatorias de la demandante de amparo debida a la pasividad del juzgado. En relación con la segunda cuestión, considera el TC que es innegable que la documentación omitida tenía virtualidad para alterar el sentido del fallo, por ello estima que la preterición por el juzgado de instrucción de la prueba documental de la defensa en el momento de enjuiciar los hechos, vulneró el derecho fundamental de la recurrente a la tutela judicial efectiva sin indefensión garantizado en el art. 24.1 CE. La demanda de amparo sostenía como segundo motivo la vulneración del derecho a la presunción de inocencia porque el juzgado no valoró la prueba de descargo, lesión que es apreciada por el TC, ya que los órganos judiciales no valoraron dicha prueba en términos válidos desde el punto de vista constitucional ${ }^{40}$.

40 Carlos Ortega Carballo. 